\title{
CEsifo \\ WORKING

\section{A Reconsideration of the Sugar Sweetened Beverage Tax in a Household Production Model}

Di Xiang, Lue Zhan, Massimo Bordignon 


\section{Impressum:}

CESifo Working Papers

ISSN 2364-1428 (electronic version)

Publisher and distributor: Munich Society for the Promotion of Economic Research - CESifo $\mathrm{GmbH}$

The international platform of Ludwigs-Maximilians University's Center for Economic Studies and the ifo Institute

Poschingerstr. 5, 81679 Munich, Germany

Telephone +49 (o)89 2180-2740, Telefax +49 (o)89 2180-17845, email office@cesifo.de

Editors: Clemens Fuest, Oliver Falck, Jasmin Gröschl

www.cesifo-group.org/wp

An electronic version of the paper may be downloaded

- from the SSRN website: $\quad$ www.SSRN.com

- from the RePEc website: $\quad$ www.RePEc.org

- from the CESifo website: www.CESifo-group.org/wp 


\title{
A Reconsideration of the Sugar Sweetened Beverage Tax in a Household Production Model
}

\begin{abstract}
We study the impact of a hypothetical tax on sugar - sweetened beverages (SSBs) on the US households' nutrients purchase, welfare change, and health benefit. Differently from the traditional approach, Food at Home(FAH) is here defined as a "home" good instead than a market good and consumers' demands derived under the assumption that households maximize utility subject to both a money and a time constraint. The model is estimated by using an incomplete approximate Exact Affine Stone Index (EASI) demand system on a data set built by merging the most recent waves of the US consumer expenditure and time use surveys. Results show that a SSB tax would be much more effective in decreasing household nutrients purchase than it would appear by estimating a model neglecting time costs in home food production. A tax induced increased in SSB price by $20 \%$ is predicted to decrease the per capita energy purchase by $29.17 \mathrm{kcal} /$ day. The annual health benefits of the tax, measured only in terms of reduced household medical expenditure, would overcome estimated welfare losses by more than \$400 million.
\end{abstract}

JEL-Codes: D120, D130, I180.

Keywords: sugar-sweetened beverage tax, obesity, household production.

Di Xiang

School of Public Finance \& Taxation Southwestern University of Finance \& Economics / Chengdu / PR China dixiang_2015@163.com
Lue Zhan

Research Institute of Economics \& Management, Southwestern University of

Finance \& Economics

Chengdu / PR China

\author{
Massimo Bordignon* \\ Department of Economics \& Public Finance \\ Catholic University \\ Italy-20123 Milan \\ massimo.bordignon@unicatt.it
}

* corresponding author

We owe thanks to Chad Lawley, who first interested us in the topic and provided much early encouragement. In particular, we would like to express our great appreciation to Gilberto Turati for his valuable comments to this research. We also thank Arthur Lewbel, and Barry Coyle for their useful suggestions. 


\section{Introduction}

The incidence of obesity is increasing in both developed and some developing countries and many recent studies discuss causes, consequences and possible remedies (e.g. Ruhm, 2012; Cawley, 2015). Among these, several health studies support the introduction of a tax on sugar - sweetened beverages (SSB, hereafter) in order to control for households' calorie intake and hence obesity. Like taxes on alcohol and tobacco, a SSB tax is a Pigovian tax designed to alter consumers' behavior. Some countries and localities have already implemented taxes on $\mathrm{SSB}^{3}$. However, the potential health and welfare impact of such a tax remains open to debate. Some studies find that a SSB tax is effective in significantly reducing SSBs consumption and hence calorie intake (Brownell et al., 2009; Finkelstein et. al., 2013; Kamerow, 2010; Sharma et al., 2014). Other scholars challenge the efficiency of the tax. They argue that a SSB tax ignores the possibility that consumers would substitute for other unhealthy food and beverages (Fletcher et al. 2010; Becker and Posner, 2009; Zhen et al., 2014a). For example, a SSB tax may reduce sugary drinks consumption, but increase consumption of snacks or other beverages high in sugar and fat. Furthermore, there is a debate on the potential welfare loss caused by imposing such a tax, especially the negative welfare impact on low-income families.

\footnotetext{
${ }^{3}$ France is the first country introduced a national wide SSB tax at $€ 7.53$ per hectoliter starting from 2012 (The Local France, 2016). In the US, there has been a growing debate around taxing soda in various cities, states and even in Congress in recent years. After implementation of Berkeley's soda tax, it is discovered that the soda consumption has decreased by $21 \%$ (Falbe et al., 2016). In addition, Philadelphia has imposed a 1.5-cents-perounce tax on SSB since January 2017 to control sugary drinks consumption.
} 
A sizable number of works use demand system estimation to study the ex-ante impact of SSB taxes (Zhen et al., 2014 a, 2014 b; Sharma et al., 2014; Allais et al., 2010). The advantage of using a demand system relies on its consistency with utility maximization theory, and therefore on the fact that results allow for welfare analysis. An ordinary demand system estimation originates from an optimization problem where households maximize utility from the consumption of a series of market goods subject to a monetary bud get constraint. Food at Home (FAH) in an ordinary demand model--either disaggregated into various food sub-categories or aggregated into one-is modeled as a market good with simply money expenditures. That is, a household "buys" FAH in the same way she might buy a meal in a restaurant. However, this approach does not take into account the fact that $\mathrm{FAH}$ is produced by also using time of the household (for cooking, cleaning and so on), so that logically the consumer maximization problem should be solved by imposing a time constraints as well. This can be important because a SSB tax might also affect the decision of how much time to dedicate to home food production. Besides, the calories intake through SSB might have different effects on the calories intake through the food consumed at home and this effect would be lost by modeling FAH as just an "expenditure". Accordingly, in this paper we investigate the impact of a SSB tax in the framework of a household production model. In this model, a household maximizes utility subject to two constraints: a money constraint and a time constraint.

In modeling the latter, we build on the large literature generated from Gary Becker (1965)'s seminal research. In his pioneer work, Becker merges goods 
expenditure with related time use in household production by applying a unitary model where the household maximizes a single utility function. As an extension to Becker's study, recent work in household production develops collective models to investigate intra-household inequality (Chiappori, 1988, 1992; Apps and Rees, 1996; Blundell, Chiappori, and Meghir, 2005; Cherchye, De Rock, and Vermeulen, 2012; Browning, Chiappori and Lewbel, 2013).

In food demand studies, some works investigate how time cost of acquiring food affect food consumption and thereby obesity. For instance, Dunn (2010) and Anderson and Matsa (2011) study how facility to restaurant access- an approximation to the time cost of obtaining Food away from Home (FAFH)- affect the Body Mass Index (BMI), and hence obesity. Focusing on the time cost involved in home food production, Hamermesh (2007) examines how households income and wage change affect time and money allocation on eating. Aguiar and Hurst (2007) investigate how households substitute time for money through shopping and home production by using both expenditure data and time use diaries. A key finding is that a food consumption series differs markedly from a food expenditure one. Using a unitary household production model, Iorwerth and Whalley (2002) find that higher taxes on food offset the non-taxation of time inputs into household production. All of these studies analyze food demand within the framework of household production theory and with time allocation included in food preparation. Given the important role that time plays in all these applications, it is surprising that no attempt has been made so 
far to set up a household production model to study the impact of a potential SSB tax on household's welfare and nutrients variation.

The present work aims to fill these gaps. Using a household production model, we simulate the impact of a SSB tax on consumers' energy and nutrients variation. We categorize food into three broad groups - FAH, SSB and FAFH - and model FAH as a home good ("Beckerian type commodity") produced by combining market goods with time inputs. ${ }^{4}$ We also include a composite time numeraire, which equals the nonworking time less time used for $\mathrm{FAH}$, and a money numeraire that represents all other goods and services that are of no direct concern for the analysis. We use an approximate Exact Affine Stone Index (EASI) demand system (Lewbel and Pendakur, 2009) to estimate the theoretical model $1^{5}$. We compute price elasticities both for our household production model and, for comparison, for an ordinary demand model that only uses money income as a constraint. Finally, based upon estimated uncompensated elasticities and nutrients data, we compute energy and other nutrients reduction after the introduction of a hypothetical SSB tax and perform a welfare analysis of the effects of the SSB tax.

Our data set is built by merging two recent different sources, the US consumer expenditure survey (CEX) (2015) and the American Time Use Survey (ATUS) (2015).

\footnotetext{
${ }^{4}$ Later in section 5 and Appendix G, we conduct some robustness exercises on food classifications. All these exercises suggest that our basic implications are robust regardless of the way food is aggregated in different categories.

${ }^{5}$ The conditional demand systems treat commodity group expenditures as fixed, and the corresponding welfare measures are simply partial welfare (LaFrance and Hanemann 1989; Hanemann and Morey 1992). As opposed to conditional demand systems, we use an incomplete demand system that permits a full welfare analysis. Larson and Shaihk (2001) and Shaikh and Larson (2003) proved that in order to guarantee the consistency of the incomplete two -constraint demand model, both a time numeraire and a money numeraire should be included in the model.
} 
To merge them, we apply a two- sample two-stage least square (2S2SLS) approach to impute time allocated to $\mathrm{FAH}^{6}{ }^{6}$ In the first step, we use a sample from time use survey and regress time use for FAH on a set of explanatory variables. In the second step, we use a sample of consumer expenditure survey, and estimate the approximate EASI demand model using the cross-sample predicted values from the first step. However, as this approach might be suspected to induce some measurement errors, we also consider, as a robustness exercise, an alternative strategy of merging CEX and ATUS by constructing specific demographic cells. Our empirical results turn out to be robust to this alternative method. ${ }^{7}$

Using a household production model considerably changes the empirical results. Compared with an ordinary demand model, the former produces a much more significant post tax reduction in energy and nutrients purchase, as SSB and FAH consumption turns out to be complements rather than substitutes. Interestingly, this is in line with the prevailing evidence in Health and Nutritional studies that typically find that a fluid carbonated calorie is not a substitute for solid calorie ${ }^{8}$. This has also deep consequences for the analysis of the welfare effects of the SSB tax. The average per capita welfare loss induced by a $20 \%$ SSB tax (as computed by using the compensating variation) turns out to be broadly similar across the two models (about

\footnotetext{
${ }^{6}$ We here follow the literature, as jointly estimating expenditure and time for households' home production is notoriously complex. Most empirical studies use a two-sample approach (e.g., Lusardi, 1996; Bjorklund and Jantti, 1997; Currie and Yelowitz, 2000; Dee and Evans, 2003; Borjas, 2004; Anderson and Matsa, 2011; Fredrikssonand Öckert, 2014; Olivetti and Paserman, 2015; Berg, Pinger, and Schoch, 2016). They use either a TS2SLS or a two-sample instrument variable (TSIV) method.

${ }^{7}$ See section 5 and Appendix Table G2.

${ }^{8}$ Details are explained in section 5 .
} 
15 dollars per year). However, the benefit -in terms of reduced calories intake, weight reduction and therefore less health expenditure ${ }^{9}-$ turns out to be much larger with the household production model (about 15.96 dollars per years, versus only 8.60 dollars in the ordinary demand model). This leads to a net per capita benefit of roughly $\$ 1.27 /$ year, or $\$ 407$ million per year when extended to the entire US population with the household production model, and to a global loss with the ordinary demand model. We also confirm that the effect of a SSB tax would be heterogeneous across the population (single - adult families would be less affected, for example) and across income groups (with lower income households that bear a higher burden for the tax). Furthermore, no significant relation between SSB and FAFH are found by using either model. In contrast, the ordinary demand model would suggest that FAH and FAFH are substitutes, whilst a household production model finds no significant substitutability/complementary effect between the two. These contrasting results emphasize the importance for policy purposes to take properly into account the time input in food preparation when estimating the effects of anti-obesity taxes on energydense, low-nutrient foods and beverages.

The rest of the paper is organized as follows. Section 2 sets up the theoretical model. Section 3 describes the data used in this paper. Section 4 presents the empirical specifications. Section 5 discusses the estimation results. Section 6 performs

\footnotetext{
${ }^{9}$ Our computations of the benefits of the SSB tax are likely to be under estimated as we only consider reduced health expenditure and not the other potential advantages for the consumers to be in better health.
} 
a counterfactual simulation on the impact of a hypothetical SSB tax on household nutrients and welfare changes. Section 7 concludes.

\section{Model Specification}

In this section, we develop a unitary household production model. We assume that labor supply is chosen in the first step. Home production, market goods consumption, and leisure are decided in the second step; that is, they are conditional upon, not jointly with labor supply. ${ }^{10}$ The primary interest of this paper is household food demand. We have three categories of food - FAH (denoted by $z_{1}$ ), SSB (denoted by $x_{2}$ ), and FAFH (denoted by $x_{3}$ ).

SSB and FAFH are market goods. FAH is interpreted as final home produced food through combining raw materials (food items bought from market) and time (used for meal preparation, cooking and cleaning up). It is expressed as $\mathrm{z}_{1}=\mathrm{z}_{1}\left(\mathrm{x}_{1}, \mathrm{~T}_{1}\right)$

where $\mathrm{x}_{1}$ is units of market goods (expenditure) used to produce FAH; $T_{1}$ is time inputs for producing FAH.

We assume that household food production follows a constant return to scale technology, ${ }^{11}$ and there is no joint production. ${ }^{12}$ In addition, we assume a Leontief

\footnotetext{
${ }^{10}$ This is different from general setup of a unitary household production model (i.e. Becker, 1965) where labor supply is jointly considered with household production, therefore, there is a substitution between work outside and home production. Since our primary interest is on how changes of food prices affect food consumption, the tradeoff between market work and home production is not our main concern in this study.

${ }^{11}$ Following Becker (1965) and Pollak and Wachter (1975), we assume constant returns to scale for the home production function. This proves to be useful for the identification strategy.

${ }^{12}$ In reality, a person may conduct several activities at one time. For example, people might be doing housework while watching TV. However, some studies find that food preparation and clean-up can be treated as a primary
} 
type of linear production technology, which is expressed as

$T_{1}=t_{1} z_{1}$

$x_{1}=b_{1} z_{1}$

where $t_{1}$ is the time input for producing one unit of $z_{1} ; b_{1}$ is an input of money per unit of $z_{1}$.

A household then faces two constraints - a money constraint and a time constraint. The money constraint is

$\mathrm{x}_{1} \mathrm{p}_{1}+\mathrm{x}_{2} \mathrm{p}_{2}+\mathrm{x}_{3} \mathrm{p}_{3}+c=M$

where $x_{2}$ and $x_{3}$ represent units of SSB and FAFH. The prices for the market goods used to produce FAH, SSB and FAFH are $p_{1}, p_{2}$ and $p_{3}$, respectively. A composite money numeraire is denoted by $c$, which equals to household's money income less the money expenditure on FAH, SSB and FAFH. The total household money income is $M$, and it includes both labor income and non-labor income.

For each household, the time budget constraint equals

$T_{1}+l=H$

where $l$ is a composite time numeraire that consists of leisure time and the time used for other home goods (i.e., gardening, cleaning and childcare). It equals to 
household's non-working time minus the time used for FAH. The $H$ is a household's total non-working time. ${ }^{13}$

Substituting equation (2) and (3) into money constraint (4) and time constraint (5), we obtain,

$z_{1} b_{1} p_{1}+x_{2} p_{2}+x_{3} p_{3}+c=M$

$z_{1} t_{1}+l=H$

To combine a money constraint with a time constraint in the model, the time input needs to be converted into dollars by using proper value of time. Following the literature (e.g. Cherchye, De Rock, Vermeulen, 2012), we use the household's wage rate (denoted by $w$ ) to measure the value of time. In turn, $w$ is derived by dividing household labor income by the household adult members' working hours. The labor income includes both wage income and self-employed income. The full budget is expressed as the summation of money budget plus time budget converted to money units by multiplying it for the marginal value of time.Without losing generality, we assume $b_{1}=1$.Using equation (6) plus equation (7) multiplied by $w$ on both sides, we obtain,

$\left(p_{1}+w t_{1}\right) z_{1}+\mathrm{x}_{2} \mathrm{p}_{2}+\mathrm{x}_{3} \mathrm{p}_{3}+w l+c=w H+M=M^{F}$

\footnotetext{
${ }^{13}$ In the empirical application, for a single-adult household, $H$ is equal to his/her total time minus his/her work time. For married-couple households, $H$ is equal to their total time minus both the husband and wife's work time.
} 
Households derive utility from FAH, SSB, FAFH, a time numeraire (other time), and a money numeraire (expenditures on other goods and services). The utility function can then be written as

$U\left(z_{1}\left(x_{1}, T_{1}\right), x_{2}, x_{3}, l, c\right)$

where $U($.$) is assumed to satisfy the usual properties with U^{\prime}()>$.0 , and $U^{\prime \prime}()<$.

Households maximize Eq. (9) subject to the bud get constraint given in Eq. (8).

Solving the first order conditions yields the optimal levels of household produced good (FAH), market goods (SSB, FAFH), time numeraire, and money numeraire, which depend on the full prices of all goods and on full income, $M^{F}$. The optimal choices can be expressed as:

$z_{1}^{*}=z_{1}^{*}\left(p_{1}+w t_{1}, p_{2}, p_{3}, M^{F}\right)$

$x_{2}^{*}=x_{2}^{*}\left(p_{1}+w t_{1}, p_{2}, p_{3}, M^{F}\right)$

$x_{3}^{*}=x_{3}^{*}\left(p_{1}+w t_{1}, p_{2}, p_{3}, M^{F}\right)$

$l^{*}=l^{*}\left(p_{1}+w t_{1}, p_{2}, p_{3}, M^{F}\right)$

$c^{*}=c^{*}\left(p_{1}+w t_{1}, p_{2}, p_{3}, M^{F}\right)$

where the $*$ superscript indicates utility maximizing levels. In the next sections, we will estimate the above theoretical model. 


\section{Data Description}

The major datasets we use are the US Consumer Expenditure Survey (CEX) (2015) and the American Time Use Survey (ATUS) (2015) ${ }^{14}$. These are the most recent consumer expenditure survey and time use survey available. The Bureau of Labor Statistics (BLS) derived a set of household weights for use with the publicly available micro data files taking into account survey design and non-response. When weighted, the sample is generally representative of the US population. In all subsequent analysis our estimations incorporates these weights.

CEX 2015 composes two major files -- a two-week goods purchase diary and a household summary file. The diary file records expenditure purchase of nondurable goods including 165 food and drink groups at household level. ${ }^{15}$ The summary file records information on a household member's income, including pre-tax salary/wage income, self-employment and investment income, other source of income and transfers, and household member's weekly working hours, as well as each member's social economic information such as age, sex, race, marital status, and family composition.

We focus our attention on couples with children, couples without children, and single-adult households (lone- parent households are included), where at least one adult member (husband and/or wife) participates in the labor market. Further, an

\footnotetext{
${ }^{14}$ The ATUS supplement data - ATUS Eating and Health Module (2015) is also used for calcu lating the average Body Mass Index in the simulation section.

${ }^{15}$ The expenditures are not recorded at individual level. The weekly household expenditure is recorded by the reference person of a family.
} 
incomplete demand system requires a non-negative numeraire good. Therefore, we drop all observations with total money income less than total food expenditure. ${ }^{16}$ After deleting apparent outliers and removing households missing important information (i.e., household income, work time), we restrict our sample to 2327 households in CEX (2015).

No food prices or quantities are recorded in CEX (2015). To address this problem we use the USDA retail food price. The USDA Economic Research Service (ERS) constructs the quarterly FAH/FAFH Price Database based on the Nielsen Homescan data. ERS aggregates food items into 54 food groups based on UPC-coded food purchases for 26 metropolitan and 9 nonmetropolitan markets for 2004-2010. By using CPI for the selected food categories, we obtain market-level food prices for 2015. ${ }^{17}$ To match the food groups of CEX with ERS food price dataset, for each dataset, we construct 37 food subcategories across 34 regions. ${ }^{18}$ The detailed common food subcategories are reported in Appendix A Table A1. Finally, we aggregate the 37

\footnotetext{
${ }^{16}$ Fifty two observations are removed from the sample. These families are low-income families with less working time. The average working time of these families are $17 \%$ less than the sample average.

${ }^{17}$ The selected monthly CPI, All Urban Consumers, is from Bureau of Labor Statistics with Series ID : CUUR0000SAF111, CUUR0000SEFC, CUUR0000SEFD, CUUR0000SEFE, CUUR0000SEFF, CUUR0000SEFG, CUUR0000SEFH, CUUR0000SEFJ, CUUR0000SAF113, CUUR0000SAF115, CUUR0000SAF114, CUUR0000SEFV, CUUR0000SA0L1.

${ }^{18}$ Boston-Cambridge-Newton, MA-NH, New York-Newark-Jersey City, NY-NJ-PA, Philadelphia-CamdenWilmington, PA-NJ-DE-MD, Chicago-Naperville-Elgin, IL-IN-WI, Detroit-Warren-Dearborn, MI, Minneapolis-St. Paul-Bloomington, MN-WI, Washington-Arlington-Alexandria, DC-VA-MD-WV, Miami-Fort Lauderdale-West Palm Beach, FL, Atlanta-Sandy Springs-Roswell, GA, Baltimore-Columbia-Towson, MD, Dallas-Fort WorthArlington, TX, Phoenix-Mesa-Scottsdale, AZ, Los Angeles-Long Beach-Anaheim, CA, San Francisco-OaklandHayward, CA, Riverside-San Bernardino-Ontario, CA, Seattle-Tacoma-Bellevue, WA, 9 other metropolitan by division, and 9 nonmetropolitan by division.
} 
food subcategories into three broad categories - FAH, SSB and FAFH. ${ }^{19}$ Notice that not all food items purchased in store are included in FAH. Specifically, we categorize in FAH food items that are commonly regarded as primary sources of energy and nutrients. Infant food, flavoring extracts and essences, and other goods and services are instead categorized into the composite money numeraire.

The American Time Use Survey (ATUS) offers a one-day time diary from nearly 21,000 individuals who had recently been interviewed by the Current Population Survey (CPS). It contains two files - a diary file and a summary file. The diary collects one (adult) household member's time usage within 24 hours. This diary provides a detailed record of one individual's participation in a wide variety of daily activities, as well as the related time devotion. It records durations for meal preparation, baking/preserving food, and meal clean-up in 24 hours for a reference member. We define time for FAH production as the summation of time used on meal preparation, baking/preserving and meal clean- up. The summary file includes information on households' income, working status and demographic information.

The time diary simply records the reference person's time uses, his/her spouse's time use is not available. ${ }^{20}$ To circumvent this difficulty, given the rich demographic information on the reference person and his/her spouse in ATUS (2015), following Hamermesh (2007), we use an imputation method similar to propensity-score

\footnotetext{
${ }^{19}$ The aggregate food prices for FAH, SSB and FAFH are constructed as a weighted average of the subcategory price with the expenditure shares for the subcategories acting as weights.

${ }^{20}$ M ost of the public time use survey record the time use for only one member (usually the reference member) in a household.
} 
matching to obtain the spouse time use on FAH. Specifically, for married-couple households we regress time in FAH for husbands (wives) with time diary on variables measuring his/her spouse's age, education, weekly working hours, race, Hispanic ethnicity, and children's age distribution. Using the estimated coefficients, we then obtain the fitted value for both husbands (wives) with time diary and without time diary. After that, we compare the fitted value of time inputs for husbands (wives) with time diary with the fitted value for husbands (wives) without time diary. If the former's fitted values are the "nearest neighbor" to the latter's, we then assign the actual time inputs of the former to the latter. ${ }^{21}$

To obtain the nutrition data for the selected food categories, we link CEX (2015) with USDA food composition database (2015) to create a nutrition profile of each household's food purchases. We are primarily interested in calorie, fat, and sodium. It is commonly acknowledged that the highly intake of energy, fat and sodium is the major cause of obesity and some chronic diseases. We first map the highly disaggregated food items in USDA food composition database with 134 CEX food subcategories. Second, within each subcategory, we calculate the mean nutrient value per unit. Third, by each household we calculate total calorie and nutrients purchase for FAH and SSB based on food quantity purchase and unit nutrients. ${ }^{22}$ The calorie, fat

\footnotetext{
${ }^{21}$ As stated by Hamermesh (2007) this imputation method is unbiased, but might sacrifice efficiency by increasing variance.

${ }^{22}$ The nutrients contained in FAH might vary across income. For example, the low income households tend to purchase lower quality food (i.e. ground pork), while the high income households might tend to purchase higher quality food (i.e., fresh vegetables, beef and fish). By calculating the nutrient components of each food subcategory within FAH and SSB, we are able to accurately predict the ex-ante impact of the SSB tax on household nutrients purchase across income.
} 
and sodium contents for FAFH are not calculated. Without information on quantity purchase of detailed food items within each meal, the accurate nutrient components for FAFH are not computable. However, this turns out not to be a problem for our analysis, as the estimation results reported in section 5 below reveal no significant complementary or substitution effects between SSB and FAFH. As a result, ignoring nutrients contained in FAFH has little impact on estimating households' nutrients variation after a SSB tax.

One potential problem in estimating a household level data is the existence of zero observations due to infrequency purchase for very disaggregated food categories. However, this is not a serious issue for our baseline model analys is as we aggregate all food cate gories in only three groups. ${ }^{23}$

Table 1 lists summary statistics used for the demand system estimation across income. $^{24}$ On average, using pooled sample, households' weekly FAH, SSB and FAFH expenditures are $\$ 85.178, \$ 4.846$, and $\$ 62.047$, respectively. The average price for FAH (SSB) is $4.920 \$ / \mathrm{kg}(0.992 \$ / \mathrm{kg})$. The average price for FAFH, including both limited - service and full-service meal, is $\$ 5.904 /$ meal. The total weekly money income for an average household is $\$ 1794.23$. The sample average wage rate is \$26.850/hour, and the household's average weekly time for working and FAH

\footnotetext{
${ }^{23}$ The degree of purchase censoring at a two-week frequencies for FAH, SSB, and FAFH are $0 \%, 44 \%$, and $18 \%$, respectively. The Tobit model or the Heckman two-step approach could potentially be used to address the problem. ${ }^{24}$ We use the OECD adjusted equivalence scale to define low and high income groups. The reference person in the family receives a factor of 1 , other adult household members each receive a factor of 0.5 , and family members under age 18 receive a factor of 0.3 . After adjusted by OECD equivalence scale, households in the CEX are then divided into low income (on average 875 dollars of household weekly equivalent income) and high income (on average 2714 dollars of household weekly equivalent income) group.
} 
production is 60.110 hours and 6.505 hours, respectively. Based on CEX (2015), the average daily per capita calorie (fat, sodium) purchase from FAH and SSB is $1795.1 \mathrm{kcal}(85.9 \mathrm{~g}, 2018.5 \mathrm{mg}) .{ }^{25}$ Further, in the empirical estimations, we incorporate several taste shifters including urbanization dummies, household size, number of kids less than 18, and number of adults aged more than 65 .

\section{Empirical s pecification}

To specify a system of demands, we apply our theoretical model into the Exact Affine Stone Index (EASI) demand system (Lewbel and Pendakur, 2009). The EASI demand system permits any shape of non-linear Engel curves (i.e. S-shaped Engel curve), which allows goods to be luxuries at some income levels and necessities at others (Pendakur 1999; Blundell, Chen and Kristensen 2007). Budget share equations that are non-linear in income/expenditure can detect nuanced differences in Engel curves and provide an accurate estimation of the Engel relationship and related welfare effects in micro-level data. Further, compared with the AIDS which is developed by Deaton and Muellbauer (1980), and other similar models, error terms in the EASI model are able to capture the unobserved preference heterogeneity. The approximate version of EASI model simplifies empirical estimation by using linear

\footnotetext{
${ }^{25}$ The summary stats are smaller than the values reported by OECD-stats. According to the OECD statistics, in 2013 the average US energy (fat) supply is $3682 \mathrm{kcal} /$ day (132.4g/day), which is far greater than the value calculated using our data. The reason for this discrepancy is that the average energy consumption using CEX is averaged among all household members including kids, while the OECD stats is the average adults energy /nutrient supply. In addition, energy and nutrients supply from FAFH, which is about $30 \%$ of the households energy supply, is not included in our summary stats.
} 
models. As discussed by Lewbel and Pendakur (2009), there is little empirical difference between exact nonlinear and approximate linear EASI estimates.

Therefore, an approximate version of EASI demand system with full prices and a full income is applied to estimate our household production model. It is expressed as:

$s_{i h}{ }^{F}=\sum_{k=1}^{J} \alpha_{i k} \ln \left(p_{k h}{ }^{F}\right)+\sum_{r=0}^{R} \beta_{i r} y_{h}^{r}+\sum_{t=1}^{T} \gamma_{i t} z_{t h}+e_{i h}$

$y_{h}=\ln M_{h}^{F}-\sum_{k=1}^{J}{\bar{s}_{k}}^{F} \ln \left(p_{k h}{ }^{F}\right)$

$i=1, \ldots, J-1 \quad h=1, \ldots, H$

where $s_{i h}{ }^{F}$ is full budget share for good $i$ for household $h$. There are altogether $H$ households, and $J$ goods in the model, where $J=5$. The full price for good $k$ for household $h$ is denoted as $p_{k h}{ }^{F}$; the parameter $\alpha_{i k}$ describes price effects. The $y_{h}$ is a measure of real full income of household $h$ with relevant coefficient $\beta_{i r}$. The exponent of $y_{h}$ is $r$, and it can be any higher order polynomial satisfying the restriction $r<J{ }^{26} \boldsymbol{z}_{\boldsymbol{h}}=\left(z_{t h}, t=1, \ldots, T\right)$ is a vector of demand shifters and $\gamma_{i t}$ is the related parameter. Finally, $e_{i h}$ is the error term.In equation (16), $M_{h}^{F}$ is the full income; the sample average full budget share of goods $i$ over all households is $\bar{S}_{k}{ }^{F} \cdot{ }^{27}$

In the empirical specification, we apply an incomplete demand system. This is because the price for other goods and services is not available. Epstein (1982) and LaFrance and Hanemann (1989) show that, by augmenting a composite numeraire

\footnotetext{
${ }^{26}$ Since we have 5 categories of goods, according to Lewbel (1991), En gel curves can be arbitrarily complex. The only restriction on $r$ is that it should be less than the number of goods categories $(r<5)$.

${ }^{27} \sum_{k=1}^{J} \bar{s}_{k}{ }^{F} \ln \left(p_{k h}{ }^{F}\right)$ is also called Stone price index (Deaton and Muellbauer, 1980).
} 
representing total expenditure on all other goods and deflating by an aggregate price index for products that are not of interest (i.e., $\pi\left(\mathrm{p}_{\mathrm{c}}\right)$ ), the augmented incomplete demand system has the same features as complete demand systems. ${ }^{28}$

A problem for our estimations is that food consumption data and the related time use data do not come from the same sample. We address this issue by applying a TS2SLS approach that combines data derived from two independent samples. The time used for FAH is thus imputed using the TS2SLS method. The detailed estimation process is divided into two stages. In the first stage, we use a sample from ATUS (2015) and regress time use for FAH on a set of explanatory variables. These include: reference person's gender, age, race, Hispanic origin, households' highest education (a vector of indicators of less than high school, some college, bachelor, master or more), variables indicating children age distribution (Number of children under 5, Number of children 6 to 12, Number of children 13 to17), adults household members' total working time, household type (couple or single), and number of people aged greater than 65 . Using the estimated coefficients and the same set of explanatory variables in CEX (2015), we obtain the cross-sample imputed time for FAH and the related full price. In the second step, we use a sample of CEX (2015) and estimate the approximate EASI demand model using the imputed full price for FAH. The detailed steps are reported in Appendix B and the estimates from the first

\footnotetext{
${ }^{28} \mathrm{LaFrance}$ and Hanemann (1989) mention that by assuming weak integrability, we have $\boldsymbol{q}(\boldsymbol{p}, y) \equiv \boldsymbol{g}\left(\frac{\boldsymbol{p}}{\pi\left(\mathrm{p}_{\mathrm{c}}\right)}, \frac{y}{\pi\left(\mathrm{p}_{\mathrm{c}}\right)}\right)$, where $\mathrm{p}_{\mathrm{c}}$ is price of other goods and services, and $\pi\left(\mathrm{p}_{\mathrm{c}}\right)$ is the price index of $\mathrm{p}_{\mathrm{c}}$. In this study, $\pi\left(\mathrm{p}_{\mathrm{c}}\right)$ is obtained from US Bureau of Labor Statistics (BLS) monthly non-food consumer price index (CPI) report.
} 
step are reported in Appendix C. We follow Inoue and Solon (2010)'s method to obtain consistent standard errors of the two -stage estimation. The detailed steps are reported in appendix D. Finally, as a robustness exercise, a different way to merge the two data sets is discussed in Section 5.

\section{Estimation Results}

To determine the proper degree of income polynomials, we test the joint significance of $\beta_{\text {ir }}$ coefficients. Wald test is used for hypotheses testing in terms of model specification. A $1 \%$ critical value is used in all hypothesis testing. Starting from $r=2$ we added one higher degree of polynomial at a time. The null hypothesis is that the $r$ th degree of polynomial is excludable. At $r=4$, the test statistic is 105.44 with a $p$ - value $<0.01 .^{29}$ Therefore, we conclude that a fourth polynomial in $y_{h}$ is sufficient to capture the Engel curves.

Figure 1-3 plot the estimated Engel curves of FAH, SSB, and FAFH for an average married-couple household living in urban area in US without children aged less than 18 and without household members aged greater than 65. Interestingly, the figures show that while the Engel curve for FAH is almost linear with a negative slope (figure 1), and the Engel curve for FAFH has a positive slope (figure 3), implying that FAH (FAFH) is an inferior (normal) good, the shape of the Engel curve for SSB is near quadratic (figure 3). That is, SSB turns out to be a normal good at some lower income levels but an inferior good as income increases.

\footnotetext{
${ }^{29}$ The test is performed by using the pooled sample.
} 


\section{Price Elasticities}

Using an approximate EASI demand model, the compensated (Hicksian) fullprice elasticity of demand for good $i$ with respect to price of good $k$ is $\varepsilon_{i k}^{F h}=\frac{1}{{\overline{S_{l}}}^{F}} \times \alpha_{i k}+s_{k}^{F}-\delta_{i k}$

Where $\varepsilon_{i k}^{F h}$ is the compensated (Hicksian) price elasticity for good $i$ to $\operatorname{good} k$. The ${\overline{S_{l}}}^{F}$ is the sample mean of the full budget share for good $i . \delta_{i k}$ is the Kronecker delta with $\delta_{i i}=1$ for own- price elasticities and $\delta_{i k}=0$ for cross- price elasticities. The uncompensated (Marshallian) full-price elasticities are recovered through the Slutsky equation: $\varepsilon_{i k}^{F h}=\varepsilon_{i k}^{F m}+\eta_{i}{ }^{F} \bar{s}_{k}^{F}$, where $\eta_{i}{ }^{F}$ is full income elasticity, and $\varepsilon_{i k}^{F m}$ is the uncompensated full-price elasticity.

Next, in order to investigate demand variations after money price change, we convert the full price elasticities for FAH derived from the estimations into its money price elasticities (hereafter, price elasticity). As the price of time is assumed to be constant, this is achieved through multiplying the full price elasticity by the ratio of money price to full price (see Appendix E).

\subsection{Baseline Results}

Table 2 reports our estimates of uncompensated price elasticities for FAH, SSB, and FAFH across income stratum. ${ }^{30}$ The left panel of the Table 2 presents the results for our household production model while, for the sake of comparison, the right panel

\footnotetext{
${ }^{30}$ The compensated (Hicksian) price elasticities are reported in the Appendix Table G1.
} 
exhibits price elasticities using the ordinary demand model. In the latter, FAH is defined as a market good (expenditure) and households maximize utility conditional on a money constraint only. Elasticities reported are evaluated at sample/subsample means. Using the ordinary demand model (right panel in Table 2), the average ownprice elasticity for SSB is $-1.300(-1.223,-1.501)$ for aggregate (low-income, highincome) households. Using a household production model (left panel in Table 2), the corresponding number for own-price elasticity for SSB is $-1.414(-1.528,-1.236)$ for aggregate (low-income, high-income) households. Clearly, both models imply that SSB is price elastic, and further there is no much difference between the two sets of results. This is because SSB is treated as a market good in both the ordinary demand model and the household production model. These estimates also fall into the reasonable range of prior studies: -0.87 from Finkelstein et al. (2013) to -2.26 from Dharmasena and Capps (2011). The differences between the above estimates are in part due to the variation of the composition of goods categories and the methodology used in estimation. Similarly, as can also be checked by Table 2, the estimated ownprice elasticities for the other market good, FAFH, are also not significantly different in the two models.

As for $\mathrm{FAH}$, we find it to be price inelastic regardless of modeling it as a home good or a market good. The uncompensated own-price elasticity for FAH in the household production model is $-0.312(-0.377,-0.262)$ using aggre gate (low-income, high-income) sample; the corresponding value for the ordinary market model is $0.419(-0.431,-0,477)$. 
Regarding cross-price elasticities, estimated results from both models imply that there is no obvious substitution/complementarities effect between SSB and FAFH ${ }^{31}$. Further, in the ordinary demand model, FAH and FAFH are found to be substitutes, using both pooling sample and subsample of low-income households, while in the household production model, there is no statistically significant relation between the two.

The crucial difference between the two models emerges when computing the cross-price elasticity of FAH to change in the price of SSB. This is estimated to be $0.025(0.021,0.027)$ for aggregate (low-income, high-income) households in an ordinary demand model, implying that SSB and FAH are substitutes. However, using a household production model, the cross-price elasticity is $-0.013(-0.018,-0.012)$ for aggregate (low-income, high-income) households, showing instead a significant complementary effects.

The explanation is that in a household production model, FAH is a final output obtained by combining food materials and time through a certain technology (Leontief production), while in an ordinary demand model, FAH is simply an expenditure. Therefore, in the household production model, the cross-price elasticity for FAH to SSB is affected by two factors - expenditure and time. That is, it is determined by the changes of FAH expenditure, as well as its time, with respect to the price of SSB. In

\footnotetext{
${ }^{31}$ It should be noted however that in this study only SSB expenditure from store is used as CEX (2015) do not separate SSBs purchase from vending machines or restaurants from other expenditures on food away from home. Perhaps, if SSB from vending machines or restaurants were also incorporated, one might observe a complementary relation between SSB and FAFH. For example, people might have pizza together with SSBs when having a meal at a restaurant.
} 
the ordinary demand model instead the cross-price elasticity for FAH to SSB is simply affected by the variation of its expenditure in response to the price change of SSB. This causes the significant discrepancies of the cross-price elasticities between FAH and SSB when using different model sets.

In addition, it should be observed that the complementary effect between SSB and FAH in the household production model finds support from the prevailing evidence in health and nutritional trials. Biological experimental studies reveal that because of the low satiety of SSBs, "compensation at subsequent meals for energy consumed in the form of a liquid could be less complete than that for energy consumed in the form of a solid" (Malik, Schulze, and Hu, 2006; Mattes, 1996). Nutritional studies also demonstrate a significant relation between consumption of SSBs and total energy intake. Increasing liquid carbohydrate consumption is not accompanied by a reduction in solid food consumption (DiMeglio and Mattes, 2000; Schulze et al., 2004; Troiano et.al. 2000; Pan and Hu, 2011). That is, the consumption of SSBs may induce hunger, thereby increased consumption of other foods. These findings imply that SSB and FAH tend to be complements, as shown by our estimates with the household production model.

We also estimate price elasticities across household types: households with children less than 18, couples without children, and single- adult households. Table 3 reports the uncompensated price elasticity varied by household type. Using the household production model, we find that the own-price elasticity of SSB for singleadult households is statistically insignificant implying that these types of households 
are irresponsive to the SSB price change. On the contrary, couples with and without children are sensitive to the price change with a corresponding own- price elasticity of -1.465 and -2.501 , respectively ${ }^{32}$. Results from the ordinary demand model also broadly confirm these results (see right panel in Table 3). Importantly, SSB and FAH are shown to be complements across all household types in the household production model while they are substitutes in the ordinary demand model.

\subsection{Robustness exercises}

Before turning to simulations, we conduct a series of alternative exercises in order to investigate the robustness of our previous results, referring specifically to the data merging approach and the food classification methods. Results from these different exercises are detailed and discussed in Appendix F and G. Here we just provide a brief summary of them.

One concern with our previous analysis is that the data we use for estimations are the result of the merger of two different datasets. Although standard in the literature, one might suspect that the methodology used for imputing time for FAH using TS2SLS approach might cause some measurement errors. As an alternative method, we then merged the two data sets by constructing demographic cells.${ }^{33} \mathrm{~A}$ limitation of the latter approach is that the cells have to be very few in number or they might end up being very sparsely populated.

\footnotetext{
${ }^{32}$ Probably "taste" is the major factor that drives the above discrepancies. Sin gle-adult households, especially the young, care more about "taste" and "flavor" rather than "health impact". Therefore, this group of people tends to be more "addictive" to SSBs. When jointly considering the habit formation of consuming SSB, it is very likely these types of households are irresponsive to price change of SSB.

${ }^{33}$ Aguiar and Hurst (2007) use this method to estimate a between effect regression by merging ATUS data into ACNielsen Homescan data.
} 
A second concern is food classification. There are two potential issues related with the food classification we used in the previous paragraphs. (1) Compared with the SSB, FAH might be too aggregated with heterogeneous items involved; and (2) food classification is complex, and there is no one-size-fits-all standard for food aggregation. For example, some food items may have multi-purposes. In some cases, they could be used as ingredients in cooking, but in others, they are ready-to-eat without cooking or cleaning time involved. For example, milk can be used as an ingredient in baking, but one can also drink it directly.

To address this second concern, we first conduct a robustness exercise by using a two-stage bud geting approach (also called "utility tree approach") developed by Strotz (1957 and 1959) and Gorman(1959). ${ }^{34}$ In this study, in the first stage a household allocates total food expenditure among broad groups of goods Unprepared/Se mi prepared FAH, Prepared FAH, Limited-service FAFH, and Full-service FAFH - based on "time" used in food. Given group expenditure in the second stage, the household chooses among elementary goods within each group. In this study, SSB Milk\&Dairy product, Fruit Juice, Snacks\&Chips, and Cakes\&Crackers are ele mentary goods within the group of Prepared FAH. The advantage of this method relies on its explicit food aggregation procedure. We also apply the general composite commodity theorem (Lewbel, 1996) to test for the separability. The disadvantage of this method is that the standard errors of the unconditional elasticities are not computable through common empirical estimation. In addition, the first-stage demand system estimation

\footnotetext{
${ }^{34}$ This method is widely used in time series data or panel data to estimate disaggregated elasticities with small number of observations.
} 
requires a complex cost-of-living price index calculation.

As a second attempt, we then classify food into more disaggre gated groups (i.e., Unprepared/Semi prepared FAH, Milk\&Dairy product, Fruit Juice, SSB,

Snacks \&Chips, Cakes \&Crackers, Limited-service FAFH, and Full-service FAFH), and estimate them in one demand system. Compared with our baseline specification, this alternative method might cause serious censoring problems.

To save space, the detailed estimation process and results for all these exercises are reported in Appendix F and Appendix Table G2-4. As shown there, however, our basic results do no change, regardless of the different empirical methods used to merge the two data sets or the different food classification approaches. Specifically, in all exercises, the own-price elasticity of SSB is price elastic using both household production model and ordinary demand model. In most of the robustness exercises when using an ordinary demand model, SSB and FAH tend to be substitutes with a positive cross-price elasticity. On the contrary, the estimates from the household production model suggest instead that SSB and FAH are complements, albeit with different food classification strategy and data merging techniques. These different predictions lead to very different conclusions concerning the desirability of a SSB tax, as shown in the next section.

\section{Simulations}

The World Health Organization (WHO) recommends at least a 20\% retail price increase on SSB in order to prominently decrease SSB consumption (WHO, 2015). 
Consequently, we simulate in this section the potential health and economic impact of a $20 \%$ tax imposed on SSB expenditure. It is equivalent to 0.56 cents/oz. We assume the tax is passed one to one onto the retail price. Thus, consumers totally bear the tax burden. ${ }^{35}$ Further, we assume that the SSB tax directly causes a shell price increase. ${ }^{36}$

\subsection{Welfare analysis}

Turning first to welfare estimates, we measure consumer welfare change by using the compensating variation $(\mathrm{CV})$.

The CV estimation in an EASI demand model (Lewbel and Pendakur, 2009;

Zhen et al., 2014a) can be expressed as:

$C V=M^{F 0}\left\{\exp \left[\left(P^{F 1}-P^{F 0}\right)^{\prime} s^{F 0}+0.5\left(P^{F 1}-P^{F 0}\right)^{\prime} \Gamma\left(P^{F 1}-P^{F 0}\right)\right]-1\right\}$

where $M^{F 0}$ is the pre-tax full income; $P^{F 1}$ is the $\mathrm{J} \times 1$ vector of the post-tax log prices, and $P^{F 0}$ is the $\mathrm{J} \times 1$ vector of pre-tax $\log$ prices. The $s^{F 0}$ captures the observed pretax full budget share. The $\Gamma$ is the $\mathrm{J} \times \mathrm{J}$ matrix of parameters whose element $\Gamma_{\mathrm{ik}}$ equals $\alpha_{\mathrm{ik}}$ in equation (20). The first term $\left(P^{F 1}-P^{F 0}\right)^{\prime} S^{F 0}$ is the Stone index for the price change assuming unchanged budget share. The second term $0.5\left(P^{F 1}-P^{F 0}\right)^{\prime} \Gamma\left(P^{F 1}-\right.$ $P F O$ captures the substitution effect.

The economic efficiency of a SSB tax is measured by the tax burden, where the

\footnotetext{
${ }^{35}$ In practice, the pass-through rate may be less than $100 \%$. For example, Cawley and Frisvold (2017) discover that $43.1 \%$ of the Berkeley tax on SSB is passed on to consumers.

${ }^{36}$ One potential concern is the tax salience issue. Chetty et al. (2009) find that consumers have heterogeneous response toward taxes and equivalent market price changes. Whether this behavioral divergence affects our simulation results depends on the way the SSB tax is imposed. If the tax is remitted by wholesalers, then the tax will totally lead to a shell price increase. In this case, tax salience issue will be eliminated. If the tax is paid at the end of purchase, say, in the checkout stage, then consumers might be more in attentive to the tax. Therefore, consumers will suffer more post tax welfare loss and gained less health benefit. In addition, we assume there is no cross-border shopping.
} 
higher the tax burden, the lower the efficiency. The tax burden is expressed as:

$T B=\frac{-\sum_{h} C V_{h}}{\sum_{h} M_{h}} \times 100 \%$

The variable $T B$ denotes the percentage tax burden.

Overall, we do not find any prominent differences in $\mathrm{CV}$ between two models.

The CV calculated using a household production model (an ordinary demand model) is denoted as $\mathrm{CV}^{\mathrm{II}}\left(\mathrm{CV}^{\mathrm{I}}\right) .{ }^{37}$ Table 4 reports the per capita annual welfare change after a $20 \%$ tax on SSB across income. Using our data, we find annually $\mathrm{CV}^{\mathrm{I}}$ is $-14.997(-$ $12.895,-17.691)$ and $\mathrm{CV}^{\mathrm{II}}$ is $-14.694(-12.261,-18.171)$ for the aggregate (low-income, high-income) households. The household tax burden created by the SSB tax is $0.043 \%$ using pool sample. Low-income individuals would suffer a higher tax burden than high-income individuals ( $0.081 \%$ vs. $0.032 \%)$. Confirming previous studies, this implies that the SSB tax is slightly regressive, since low-income households suffer more tax burdens than high-income households.

We also calculate how CVs vary by demographic status; the results are reported in Table 5. Using the household production model, we find that the SSB tax generates a greater welfare loss for single-adult households $(0.055 \%)$ compared with other types of households $(0.047 \%$ for couples with children and $0.028 \%$ for couples without

\footnotetext{
${ }^{37}$ Notice that on theoretical grounds we cannot make predictions about the relative size of $\mathrm{CV}^{\mathrm{I}}$ with respect toCV ${ }^{\mathrm{II}}$ as there are different forces at play. On the one hand, the household production model allows households to change their budget allocations between other time and SSB following a price increase in SSB, while this is not possible in an ordinary demand model. This should make $\mathrm{CV}^{\mathrm{II}}$ less than $\mathrm{CV}^{\mathrm{I}}$ in magnitude. On the other hand, in the household production model, the FAH is a home good instead of a market good and therefore the estimated substitution effect between the SSB and FAH is different than in an ordinary demand model. This might lead $\mathrm{CV}^{\mathrm{II}}$ to be greater than $\mathrm{CV}^{\mathrm{I}}$. The overall effect is ambiguous.
} 
children). Intuitively, as the demand for SSB is price inelastic for single-adult households, they suffer a higher welfare cost for the introduction of the tax. Regarding to the tax burden, both models imply that a SSB tax generates more tax burden for single-adult households, followed by couples with children, and couples without children.

\subsection{Nutrients Impact}

The impact of the SSB tax on household nutrients depends on the magnitude of SSBs' own-price elasticity and the sign and magnitude of its related cros s-price elasticities. Table 6 summarizes the simulated average effects on households' calorie, fat, and sodium purchase across income strata based on uncompensated price elasticities from both models. We begin with the ordinary demand model. Overall, a $20 \%$ price increase of SSB reduces an average per capita energy purchase by 15.65 kcal/day using pooling sample. The disaggregate effects reveal that most of the energy reduction comes directly from the decrease of SSB (22.95 kcal). Since FAH is estimated to be a substitute for SSB, a 20\% SSB tax increases FAH purchase, and raises per capita energy consumption by $7.30 \mathrm{kcal} / \mathrm{day}$. The SSB tax also generates an increase in per capita fat purchase by $0.34 \mathrm{~g}$, while we do not find a significant impact on households' sodium expenditure. In a closely related study using the same demand function form (approximate EASI demand), albeit with more disaggregated food classifications, Zhen et al. (2014a) find an overall substitution effect between SSB and all other 22 food categories. Therefore, using an ordinary demand model, our results would support Becker and Posner(2009)'s conclusion of the inefficiency of the soda 
tax, as this just leads to substituting for energy from other food.

However, when using a household production model, a $20 \%$ tax induced increase in the price of SSB is much more effective in decreasing energy and other nutrients purchase, because of the difference in cross-price elasticities between FAH and SSB. Looking more in detail to the disaggregate effects of the $20 \%$ increase in SSB price in the household production model, we first find that most of the energy decrease is attributable to SSB (24.94 kcal/day) reduction. This is similar to the prediction from the ordinary demand model. However, as SSB and FAH consumption are complements in the household production model, the SSB tax will also cause a reduction in FAH consumption. Consequently, the tax generates an overall reduction of energy by $29.17 \mathrm{kcal} / \mathrm{day}$ using pooling sample. Across income, we find that the tax decreases the per capita energy purchase by 31.69 (26.89) kcal for high-income (low-income) households, among which $27.21 \mathrm{kcal}(22.59 \mathrm{kcal})$ is from SSB and $4.48 \mathrm{kcal}(4.30 \mathrm{kcal})$ is from FAH consumption.

Table 7 reports the post-tax energy and nutrients expenditure varied by demographic status. Compared with the ordinary demand model, the household production model generates a sharper reduction in energy and nutrients purchase for married couples without children $(69.87 \mathrm{kcal}$ in the household production model v.s. $27.74 \mathrm{kcal}$ in the ordinary demand model) and couples with children (29.96kcal from the household production model, but statistically insignificant from the ordinary demand model) due to the significant differences of the estimated own-price elasticity of SSB. Regarding to the single- adult households, we find that the daily per capita 
energy reduction is statistically insignificant in both model sets.

Summing up, our simulation results imply that a SSB tax is more effective in reducing energy and other nutrient purchase when incorporating the time forgone in home food production. In other words, the traditional demand system grossly underestimates the impact of a SSB tax on household energy and nutrients reduction.

\subsection{Health Impact}

In the long run, a tax on SSB would also induce a cumulative per capita body weight loss; and as suggested by an abundant medical literature, reduced body weight is also expected to produce a number of health benefits for consumers. To provide some estimations of these benefits, we focus here on the relationship between body weight and medical expenditure. The existing literature demonstrates that body weight loss has a direct relation with reduction in medical expenditure. To estimate these benefits, we then firstly convert the predicted daily energy reduction induced by the SSB tax into potential weight loss. Using the dynamic model proposed by Lin et al. (2011), the predicted weight loss at year 5 would be around $1.54 \mathrm{~kg}$ when using the household production model and $0.83 \mathrm{~kg}$ when using the ordinary demand model ${ }^{38}$. According to Cawley and Meyerhoefer (2012)'s instrument variable estimation, an additional unit of Body Mass Index (BMI) is associated with $\$ 149$ higher annual expenditures. The supplement data of the time use survey, ATUS - Eating and Health Module (2015), records the reference person's Body Mass Index(BMI) and other health indicators. Table H1 in the

\footnotetext{
${ }^{38}$ That is, the average annual weight loss is around $0.308 \mathrm{~kg} / \mathrm{capita}(0.166 \mathrm{~kg} / \mathrm{c}$ apita $)$ in the household production model (ordin ary demand model).
} 
Appendix $\mathrm{H}$ reports the average adult BMI, weight, and height varied across income and demographic status. Therefore, our most conservative estimation implies an annual per capita average $\$ 15.96$ saving in medical expenditure using the household production model and $\$ 8.60$ using the ordinary demand model. ${ }^{39}$

Finally, we estimate the net benefit of a $20 \%$ SSB tax. We show before that the price increase in SSB will cause a consumer welfare loss, as measured by the CV. In the long run however, such a tax would also reduce body weight, and thus reduces medical costs. The net benefit is measured by the difference between the health benefits and consumer welfare loss. In a household production model, the medical benefit of the $20 \%$ SSB tax is greater than the potential cost as measured by CV. The annual per capita net benefit is $\$ 1.265 /$ year for pooling sample, that is, approximately $\$ 407$ million when extended to the total US population ${ }^{40}$. On the contrary, using the ordinary demand model, the annual per capita net benefit would be negative, \$6.396/year. This shows the importance of using a household production model for food policy analysis.

\section{Concluding re marks}

This paper studies the impact of a hypothetical SSB tax on household nutrients purchase and related economic and health effects within the framework of a household production model estimated using an incomplete two-constraint

\footnotetext{
${ }^{39}$ We do not calculate the reduction of health costs caused by variation of nutrients. For example, the reduction of sodium will decrease the possibility of cardiovascular disease burden, and thus health costs. Without considering the impact of the health cost reduction caused by variation in nutrients (i.e., fat, sodium), our approximation of the health benefits of the SSB tax is likely to underestimate the true effects.

${ }^{40}$ According to the U.S. Bureau of the Census, the population in U.S. in 2015 is $321,418,820$.
} 
approximate EASI demand system. Differently from the ordinary demand model that has been so far used in the literature, where households are subject only to a money constraint, we acknowledge that food-consumed-at-home is a home good produced by a combination of market goods (expenditure) and food cooking/cleaning up time. Therefore, we derive household demands as the result of a utility maximization exercise under a resource constraint that takes into accounts both money and time. The model is estimated with the most recent US expenditure data, merging together two different data sets, and using different alternative methods to compute the time dedicated to food home production.

The results pay off for the extra effort. We show that the ordinary demand model, that treats food at home as an expenditure and thus does not consider the time involved in home production, underestimates the effect of a tax on sugar - sweetened beverages in reducing households energy and other nutrients purchase with respect to the household production model. Specifically, while in the ordinary model any effort in reducing calories intake by the imposition of a SSB tax is largely offset by increasing consumption of other food high in calories, the household production model suggests instead that food at home and SSB are complements. Importantly, these results are in line with the Health and Nutritional literature that suggests overall very limited substitution effects between fluid carbonated calorie and solid calorie. Thus, the reduction in calories induced by the tax is not compensated by extra consumption of calories at home (or outside home, as we also show that a SSB tax would also not affect food consumed away from home). 
Our results have also strong implications for policy. Overall, they are more favorable to the imposition of an SSB tax than the ones derived by the traditional literature. We confirm that the effect of an SSB tax would be heterogeneous across the population (single-adult families would be less affected, for example), and across income groups (with lower income households that support a higher burden for the tax). On the other hand, welfare analysis and simple back of the envelope computations suggest that the benefits of the SSB tax would likely overcome the costs at least on average ${ }^{41}$. Even limiting these health benefits to reduced health expenditure induced by body weight losses these are more than enough to compensate for the welfare costs of the tax, netting a positive gain around $\$ 400$ million per year when extended to the entire US population.

Summing up, the paper then speaks clearly for the need of considering explicitly the use of time in the study of the impact of food policies on consumer's behavior, by estimating a household production model.

\footnotetext{
${ }^{41}$ This even without considering that the revenues produced by the SSB tax could be used to provide extra benefits to the consumers.
} 


\section{References}

Aguiar, M., Hurst, E., 2007. Life-cycle prices and production. The American economic review 97(5), 1533-1559.

Allais, O., Bertail, P., Nichele, V., 2010. The Effects of A Fat Tax on French Household s' Purchases: A Nutritional Approach. American Journal of Agricultural Economics 92(1), 228-245.

Anderson, M.L., Matsa, D.A., 2011. Are Restaurants Really Supersizing America? American Economic Journal: Applied Economics 3(1), 152-188(37).

Angrist, J.D., Krueger., A.B., 1992. The Effect of Age at School Entry on Educational Attainment: An Application of Instrumental Variables with Moments from Two Samples. Journal of the American Statistical Association 87, 328-336.

Apps, P. F., Rees, R., 1996. Labour Supply, Household Production and Intra-family Welfare Distribution. Journal of Public Economics 60(2), 199-219.

Becker, G.S.,1965. A Theory of the Allocation of Time. Economic Journal 75, 493517.

Becker, G.S., Posner, R.A., 2009. http://www.becker-posner-

blog.com/2006/10/taxing-fat-becker.html.

Berg, G.J., Pinger, P.R., Schoch, J., 2016. Instrumental variable estimation of the causal effect of hunger early in life on health later in life. The Economic Journal 126(591), 465-506. 
Bjorklund, A., Jantti, M., 1997. Intergenerational Income Mobility in Sweden Compared to the United States. American Economic Review 87, 1009-1018.

Blundell, R., Chiappori, P., Meghir , C., 2005. Collective Labour Supply with Children. Journal of Political Economy 113(6), 1277-1306.

Blundell, R., Chen, X.H., Kristensen, D., 2007. Nonparametric IV Estimation of Shape-Invariant Engel curves. Econometrica 75, 1613-1669.

Borjas, G.J., 2004. Food Insecurity and Public Assistance. Journal of Public Economics 88, 1421-1443.

Brownell, K.D., Farley, T., Willett, W.C., Popkin, B.M., Chaloupka, F.J., Thompson, J.W., Ludwig, D.S., 2009. The Public Health and Economic Benefits of Taxing Sugar-Sweetened Beverages. The New England Journal of Medicine 361(16), 15991605.

Browning, M., Chiappori, P., Lewbel, A., 2013. Estimating Consumption Economics of Scale, Adult Equivalence Scales, and Household Bargaining Power. Review of Economic Studies 80, 1267-1303.

Cawley, J., Fris vold, D., 2017. The Incidence of Taxes on Sugar-Sweetened Beverages: The Case of Berkeley, California. Journal of Policy Analysis and Management 36(2), 303-326.

Chetty, R., Looney, A., Kroft, K., 2009. Salience and Taxation: Theory and Evidence. American Economic Review 99(4), 1145-1177. 
Cawley, J., Meyerhoefer, C., 2012. The medical care costs of obesity: An instrumental variables approach. Journal of Health Economics 31(1), 219-230.

Cawley, J., 2015. An economy of scales: A selective review of obesity's economic causes, consequences, and solutions. Journal of Health Economics 43 (1), 244-268.

Cherchye, L., De Rock, B., Vermeulen, F., 2012. Married with Children: A Collective Labour Supply Model with Detailed Time Use and Intra-household Expenditure Information. American Economic Review 102(7), 3377-3405.

Currie, J., Yelowitz, A., 2000. Are Public Housing Projects Good for Kids? Journal of Public Economics 75, 99-124.

Chiappori, P., 1988. Rational Household Labor Supply. Econometrica 56(1), 63-90.

Chiappori, P., 1992. Collective Labor Supply and Welfare. Journal of Political Economy 100(6), 437-467.

Deaton, A., Muellbauer, J., 1980. An Almost Ideal Demand System. The American Economic Review 70(3), 312-326.

Dee, T. S., Evans, W. N., 2003. Teen Drinking and Educational Attainment: Evidence from Two-Sample Instrumental Variables Estimates. Journal of Labor Economics 21, $178-209$.

Dharmasena, S., Capps, O.J. 2012. Intended and unintended consequences of a proposed national tax on sugar-s weetened beverages to combat the U.S. obesity problem. Health Economics 21(6), 669-94.

DiMeglio, D.P., Mattes, R.D., 2000. Liquid versus solid carbohydrate: effects on food 
intake and body weight. Int J Obes Relat Metab Disord 24, 794 - 800.

Dunn, R.A., 2010. The effect of fast-food availability on obesity: an analysis by gender, race, and residential location. American Journal of Agricultural Economics 92, $1149-1164$.

Epstein, L.G.,1982. Integrability of Incomplete Systems of Demand Functions. The Review of Economic Studies 49(3), 411-425.

Falbe, J., Thompson, H.R., Becker C.M., Rojas, N., McCulloch, C.E., Madsen, K.A., 2016. Impact of the Berkeley Excise Tax on Sugar-Sweetened Beverage Consumption. American Journal of Public Health 106, 1865-1871.

Finkelstein, E.A., Zhen, C., Bilger, M., Nonnemaker, J., Farooqui, A.M., Todd, J.E., 2013. Implications of a sugar-sweetened beverage (SSB) tax when substitutions to non-beverage items are considered. Journal of Health Economics 32(1), 219-239.

Fletcher, J., Fris vold, D., Tefft, N., 2010. The effects of soft-drink taxes on child and adolescent consumption and weight outcomes. Journal of Public Economics 94(11), 967-974.

Fredriksson, P., Öckert, B., 2014. Life - cycle Effects of Age at School Start. The Economic Journal 124(579), 977-1004.

Gorman, W.M., 1959. Separable Utility and Aggregation. Econometrica 27(3), 469481.

Hamermesh, D., 2007. Time to eat: Household production under increasing income inequality. American Journal of Agricultural Economics 89(4), 852-863. 
Inoue, A., Solon, G., 2010. Two-Sample Instrumental Variables Estimators. The Review of Economics and Statistics 92(3), 557-561.

Iorwerth, A.A., Whalley, J., 2002. Efficiency considerations and the exemption of food from sales and value added taxes. Canadian Journal of Economics 35, 166-182.

Kamerow, D., 2010. The case of the sugar sweetened beverage tax. British Medical Journal, 341.

Larson, D.M., Shaikh, S.L., 2001. Empirical Specification Requirements for TwoConstraint Models of Recreation Demand. American Journal of Agricultural Economics 83, 428-440.

LaFrance, J.T., Hanemann, W.M., 1989. The dual structure of incomplete demand systems. American Journal of Agricultural Economics 71(2), 262-274.

Hanemann, M., Morey, E., 1992. Separability, partial demand systems, and consumer's surplus measures. Journal of Environmental Economics and Management 22(3), 241-258.

Lewbel, A., 1991. The Rank of Demand Systems: Theory and Nonparametric Estimation. Econometrica 59, 711-730.

Lewbel, A. 1996. Aggregation Without Separability: A Generalized Composite Commodity Theorem. The American Economic Review. 86(3),524-542.

Lewbel, A., Pendakur, K., 2009. Tricks With Hicks: The EASI Demand System. American Economic Review 99(3), 827-863.

Lin, B.-H., Smith, T.A., Lee, J.-Y., Hall, K.D., 2011. Measuring weight outcomes for 
obesity intervention strategies: the case of a sugar-sweetened beverage tax. Economics \& Human Biology 9, 329-341.

The Local France, 2016. France could hike taxes on soda and chocolate bars. http://www.thelocal.fr/20160622/the-price-of-sugary-drinks-in-france-may-be-on-the-rise Lusardi, A., 1996. Household Saving: Micro Theories and Micro Facts. Journal of Economic Literature 34(4), 1797-1855.

Malik, V.B., Schulze, M. B., Hu, F. B. 2006. Intake of sugar-sweetened beverages and weight gain: a systematic review. Am J Clin Nutr 84, 274-88.

Mattes RD.1996. Dietary compensation by humans for supplemental energy provided as ethanol or carbohydrate in fluids. Physiol Behav 59,179-87.

Murphy, K. M., and R. H. Topel. 1986. Estimation and Inference in Two-Step Econometric Models. Journal of Business and Economic Statistic, 3, 370-379.

OECD.Statistics. 2017.Non-Medical Determinants of Health: Food supply and consumption.http://stats.oecd.org/index.aspx?queryid=30126\#

Olivetti, C., Paserman, M.D., 2015. In the name of the son (and the daughter): Intergenerational mobility in the United States, 1850-1940. The American Economic Review 105(8), 2695-2724.

Pan, A., Hu, FB., 2011. Effects of carbohydrates on satiety: differences between liquid and solid food. Curr Opin Clin Nutr Metab Care 14(4), 385-390. 
Pendakur, K., 1999. Estimates and Tests of Base-Independent Equivalence Scales. Journal of Econometrics 88, 1-40.

Pollak, R. A., Wachter M. L. 1975. The Relevance of the Household Production Function and Its Implications for the Allocation of Time. Journal of Political Economy 83 (2), 255-77.

Ruhm, C.J., 2012. Understanding overeating and obesity. Journal of Health Economics31, 781-796.

Shaikh, S. L., and D. M. Larson. 2003. A Two-Constraint Almost Ideal Recreation Demand System. The Review of Economics and Statistics 85(4),953-961.

Sharma, A., Hauck, K., Hollingsworth, B., Siciliani, L., 2014. The Effects of Taxing Sugar-Sweetened Beverages across Different Income Groups. Health Economics 23(9), 1159-1184.

Strotz, R.H., 1957. The Empirical Implications of a Utility Tree. Econometrica 25(2), $269-280$.

Strotz, R.H., 1959. The Utility Tree-A Correction and Further Appraisal. Econometrica 27(3), 482-488.

Schulze, M.B., Manson, J.E., Ludwig, D.S., Colditz, G.A., Stampfer, M.J., Willett, W.C., Hu, F.B., 2004. Sugar-sweetened beverages, weight gain, and incidence of type 2 diabetes in young and middle-aged women. JAMA 292, 927-34.

Troiano, R.P., Briefel, R.R., Carroll, M.D., Bialostosky, K., 2000. Energy and fat intakes of children and adolescents in the United States: data from the National Health 
and Nutrition Examination Surveys. Am J Clin Nutr 72, 1343S-53S.

World Health Organization, 2015. Fiscal Policies for Diet and Prevention of

Noncommunicable Diseases. WHO, Geneva. Switzerland.

Zhen, C., Finkelstein, E.A., Nonnemaker, J., Karns, S., Todd, J.E., 2014 a. Predicting the Effects of Sugar-sweetened Beverage Taxes on Food and Beverage Demand in a Large Demand System. American Journal of Agricultural Economics 96, 1-25.

Zhen, C., Brisette, I.F., Ruff, R.R., 2014b. By ounce or by calorie: The differential effects of alternative sugar-sweetened beverage tax strategies. American Journal of Agricultural Economics 96(4), 1070-1083. 
Figure 1-Figure 3

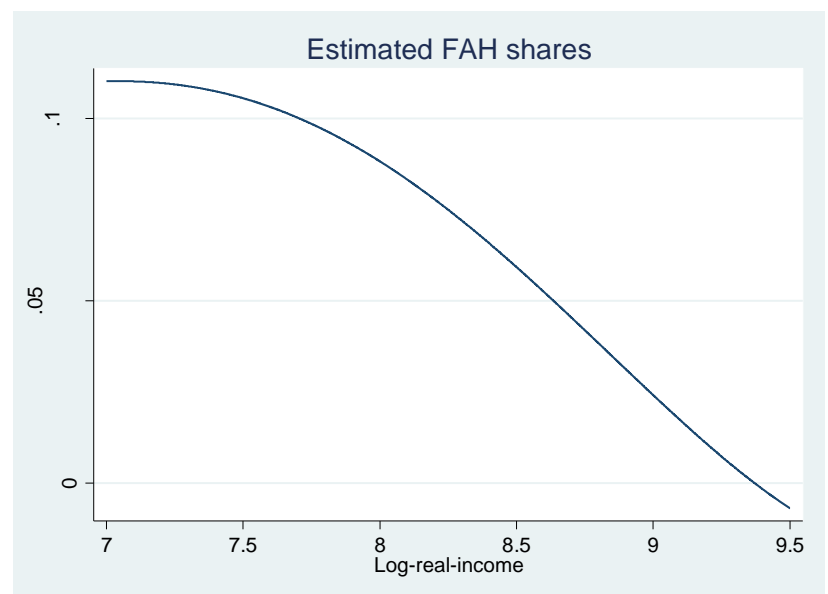

Figure 1. Estimated FAH Shares

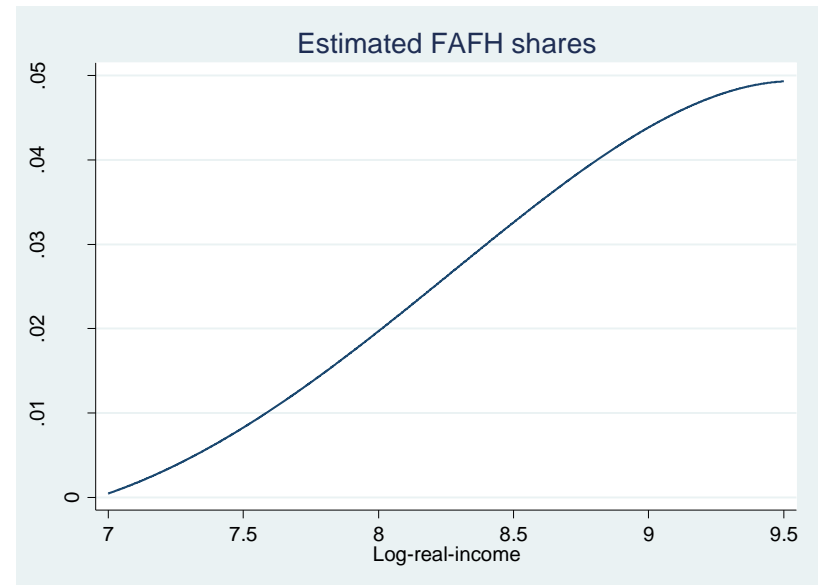

Figure 3. Estimated FAFH Shares

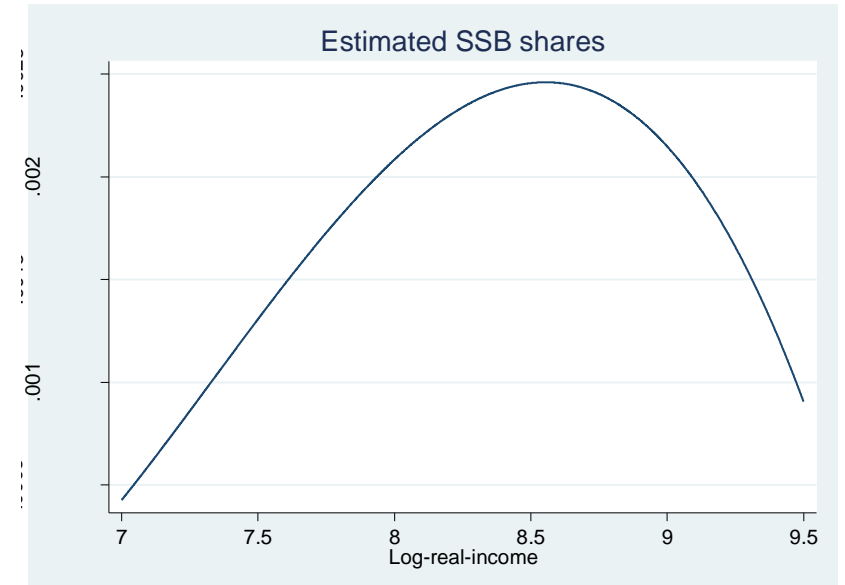

Figure 2. Estimated SSB Shares 
Table1. Descriptive Statistics

\begin{tabular}{|c|c|c|c|c|c|c|}
\hline & \multicolumn{2}{|c|}{ Aggre gate (2327) } & \multirow[t]{2}{*}{ Low(1164) } & \multicolumn{3}{|c|}{$\operatorname{High}(1163)$} \\
\hline & \multirow{3}{*}{ Mean } & \multirow[t]{2}{*}{ Standard } & & \multirow[t]{2}{*}{ Standard } & \multicolumn{2}{|r|}{ Standard } \\
\hline & & & Mean & & Mean & \\
\hline & & \multicolumn{2}{|l|}{ deviation } & deviation & & deviation \\
\hline \multicolumn{7}{|l|}{ Expenditure(\$/week) } \\
\hline FAH & 79.261 & 61.483 & 69.240 & 55.653 & 89.290 & 65.313 \\
\hline SSB & 4.525 & 7.004 & 4.193 & 6.144 & 4.859 & 7.759 \\
\hline FAFH & 61.068 & 70.170 & 35.960 & 41.400 & 80.752 & 81.108 \\
\hline \multicolumn{7}{|l|}{ Price $(\$ / k g)$} \\
\hline $\begin{array}{l}\text { FAH (money } \\
\text { price) }\end{array}$ & 4.876 & 1.171 & 4.748 & 1.162 & 5.003 & 1.167 \\
\hline SSB & 0.992 & 0.091 & 0.989 & 0.083 & 0.996 & 0.090 \\
\hline FAFH (C\$/meal) & 5.904 & 1.905 & 5.646 & 1.871 & 6.208 & 2.058 \\
\hline Weekly Income (\$) & 1794.230 & 1489.814 & 875.078 & 491.960 & 2714.172 & 1583.466 \\
\hline wage rate $(\$ / h r)$ & 26.850 & 20.644 & 16.324 & 15.636 & 37.386 & 19.655 \\
\hline \multicolumn{7}{|l|}{ Time(hours/week) } \\
\hline Work time & 60.110 & 24.748 & 52.463 & 22.647 & 67.764 & 24.403 \\
\hline Cook time ${ }^{42}$ & 6.505 & 2.931 & 6.908 & 3.148 & 6.101 & 2.636 \\
\hline \multicolumn{7}{|c|}{ Total energy ( kcal/day) } \\
\hline FAH & 1690.263 & 1358.314 & 1400.546 & 1167.749 & 1980.229 & 1469.749 \\
\hline SSB & 104.982 & 183.064 & 91.603 & 161.876 & 118.372 & 201.239 \\
\hline \multicolumn{7}{|l|}{ Total fat (g/day) } \\
\hline FAH & 85.757 & 76.859 & 71.274 & 66.413 & 100.254 & 83.604 \\
\hline SSB & 0.149 & 0.273 & 0.131 & 0.244 & 0.167 & 0.298 \\
\hline \multicolumn{7}{|c|}{ Total sodium (mg/day) } \\
\hline FAH & 1980.246 & 1692.114 & 1644.607 & 1456.172 & 2316.173 & 1839.395 \\
\hline SSB & 38.299 & 67.833 & 32.517 & 53.834 & 44.086 & 79.012 \\
\hline
\end{tabular}

\footnotetext{
${ }^{42}$ The cook time, including time for food preparation, and cleaning up, is imputed by using TS2SLS method.
} 
Table 2.Mashallian price elasticities across income(household production model vs. ordinary EASI demand model)

\begin{tabular}{|c|c|c|c|c|c|c|c|}
\hline \multicolumn{4}{|c|}{ Household Production Model } & \multicolumn{4}{|c|}{ Ordinary EASI Demand Model } \\
\hline \multicolumn{4}{|c|}{ Aggregate } & \multicolumn{4}{|c|}{ Aggregate } \\
\hline & P_FAH & P_SSB & P_FAFH & & P_FAH & P_SSB & P_FAFH \\
\hline \multirow[t]{2}{*}{ FAH } & -0.312 & -0.013 & -0.005 & FAH & -0.419 & 0.025 & 0.085 \\
\hline & $(0.005)$ & $(0.002)$ & $(0.012)$ & & $(0.076)$ & $(0.009)$ & $(0.042)$ \\
\hline \multirow[t]{2}{*}{ SSB } & -0.121 & -1.414 & -0.139 & SSB & 0.415 & -1.300 & -0.074 \\
\hline & $(0.019)$ & $(0.465)$ & $(0.121)$ & & $(0.155)$ & $(0.408)$ & $(0.109)$ \\
\hline \multirow[t]{4}{*}{ FAFH } & -0.005 & -0.013 & -0.585 & FAFH & 0.113 & -0.009 & -0.562 \\
\hline & $(0.010)$ & $(0.011)$ & $(0.074)$ & & $(0.066)$ & $(0.010)$ & $(0.073)$ \\
\hline & \multicolumn{3}{|c|}{ Low } & \multicolumn{4}{|c|}{ Low } \\
\hline & P_FAH & P_SSB & P_FAFH & & P_FAH & P_SSB & P_FAFH \\
\hline \multirow[t]{2}{*}{ FAH } & -0.377 & -0.018 & -0.023 & FAH & -0.431 & 0.021 & 0.101 \\
\hline & $(0.009)$ & $(0.003)$ & $(0.017)$ & & $(0.096)$ & $(0.012)$ & $(0.052)$ \\
\hline \multirow[t]{2}{*}{ SSB } & -0.164 & -1.528 & -0.186 & SSB & 0.357 & -1.223 & -0.105 \\
\hline & $(0.031)$ & $(0.616)$ & $(0.151)$ & & $(0.188)$ & $(0.542)$ & $(0.136)$ \\
\hline \multirow[t]{4}{*}{ FAFH } & -0.020 & -0.021 & -0.627 & FAFH & 0.150 & -0.015 & -0.566 \\
\hline & $(0.019)$ & $(0.018)$ & (0.109) & & $(0.097)$ & $(0.015)$ & $(0.106)$ \\
\hline & & High & & & & High & \\
\hline & P_FAH & P_SSB & P_FAFH & & P_FAH & P_SSB & P_FAFH \\
\hline \multirow[t]{2}{*}{ FAH } & -0.262 & -0.012 & -0.010 & FAH & -0.477 & 0.027 & 0.061 \\
\hline & $(0.004)$ & $(0.002)$ & $(0.014)$ & & $(0.082)$ & $(0.012)$ & $(0.050)$ \\
\hline \multirow[t]{2}{*}{ SSB } & -0.136 & -1.236 & 0.010 & SSB & 0.485 & -1.501 & 0.058 \\
\hline & $(0.021)$ & $(0.556)$ & $(0.154)$ & & $(0.209)$ & $(0.522)$ & $(0.147)$ \\
\hline \multirow[t]{2}{*}{ FAFH } & 0.002 & 0.001 & -0.526 & FAFH & 0.061 & 0.003 & -0.552 \\
\hline & $(0.010)$ & $(0.010)$ & $(0.086)$ & & $(0.057)$ & $(0.009)$ & $(0.082)$ \\
\hline
\end{tabular}

Note: Standard errors are reported in parentheses. Only selected elasticities (FAH, SSB and FAFH) that are our direct interests in this research are reported; the elasticity of "othertime" in the household production model are not reported. 
Table 3.Mashallian price elasticities varied by demographic status (household production model vs. ordinary

EASI demand model)

\begin{tabular}{|c|c|c|c|c|c|c|c|}
\hline \multicolumn{4}{|c|}{ Household Production Model } & \multicolumn{4}{|c|}{ Ordinary EASI Demand Model } \\
\hline \multicolumn{4}{|c|}{ Households with kids } & \multicolumn{4}{|c|}{ Household with kids } \\
\hline & P_FAH & P_SSB & P_FAFH & & P_FAH & P_SSB & P_FAFH \\
\hline FAH & $(0.006)$ & $(0.003)$ & $(0.015)$ & & $(0.115)$ & $(0.014)$ & $(0.059)$ \\
\hline \multirow[t]{2}{*}{ SSB } & -0.130 & -1.465 & 0.021 & SSB & 0.658 & -1.083 & 0.213 \\
\hline & $(0.024)$ & $(0.581)$ & $(0.157)$ & & $(0.230)$ & $(0.566)$ & $(0.156)$ \\
\hline FAFH & $(0.014)$ & $(0.017)$ & $(0.108)$ & & $(0.105)$ & $(0.017)$ & $(0.108)$ \\
\hline \multicolumn{4}{|c|}{ Couples without kids } & \multicolumn{4}{|c|}{ Couples without kids } \\
\hline & P_FAH & P_SSB & P_FAFH & & P_FAH & P_SSB & P_FAFH \\
\hline FAH & -0.289 & -0.017 & 0.005 & FAH & -0.462 & 0.006 & 0.086 \\
\hline \multirow[t]{2}{*}{ FAFH } & -0.006 & -0.020 & -0.616 & FAFH & 0.108 & -0.016 & -0.610 \\
\hline & $(0.017)$ & $(0.018)$ & $(0.118)$ & & $(0.107)$ & $(0.016)$ & $(0.120)$ \\
\hline \multicolumn{4}{|c|}{ Single-adult } & \multicolumn{4}{|c|}{ Single-adult } \\
\hline & P_FAH & P_SSB & P_FAFH & & P_FAH & P_SSB & P_FAFH \\
\hline \multirow[t]{2}{*}{ FAH } & -0.409 & -0.014 & 0.008 & FAH & -0.488 & 0.014 & 0.003 \\
\hline & $(0.013)$ & $(0.005)$ & $(0.034)$ & & $(0.144)$ & $(0.020)$ & $(0.089)$ \\
\hline \multirow[t]{2}{*}{ SSB } & -0.111 & -1.107 & -0.400 & SSB & 0.218 & -1.140 & -0.518 \\
\hline & $(0.048)$ & $(0.849)$ & $(0.243)$ & & $(0.315)$ & $(0.795)$ & $(0.234)$ \\
\hline FAFH & 0.032 & -0.033 & -0.628 & FAFH & -0.014 & -0.045 & -0.628 \\
\hline
\end{tabular}

Note: Standard errors are reported in parentheses. Only selected elasticities (FAH, SSB and FAFH) that are our direct interests in this research are reported; the elasticity of "othertime" in the household production model are not reported. 
Table 4.The impact of annual welfare changes across income

\begin{tabular}{|c|c|c|c|c|c|c|}
\hline & \multicolumn{3}{|c|}{ Household Production Model } & \multicolumn{3}{|c|}{ Ordinary EASI Demand Model } \\
\hline & Aggregate & Low & High & Aggregate & Low & High \\
\hline \multicolumn{7}{|l|}{ CV (\$/capita) } \\
\hline -Stone effect & -15.707 & -13.250 & -18.679 & -15.710 & -13.255 & -18.681 \\
\hline \multirow[t]{2}{*}{-Total effect } & -14.694 & -12.261 & -18.171 & -14.997 & -12.895 & -17.691 \\
\hline & $(1.130)$ & $(1.151)$ & (1.199) & $(0.956)$ & $(0.848)$ & $(1.027)$ \\
\hline Tax Burden & $0.043 \%$ & $0.081 \%$ & $0.032 \%$ & $0.044 \%$ & $0.085 \%$ & $0.031 \%$ \\
\hline
\end{tabular}

Note: Standard errors are reported in parentheses 
Table 5.The impact of annual welfare changes by demographic status

\begin{tabular}{|c|c|c|c|c|c|c|}
\hline & \multicolumn{3}{|c|}{ Household Production Model } & \multicolumn{3}{|c|}{ Ordinary Demand Model } \\
\hline & $\begin{array}{l}\text { Households with } \\
\text { kids }\end{array}$ & $\begin{array}{l}\text { Couples w/o } \\
\text { kids }\end{array}$ & Single & $\begin{array}{l}\text { Households } \\
\text { with kids }\end{array}$ & $\begin{array}{l}\text { Couples w/o } \\
\text { kids }\end{array}$ & Single \\
\hline \multicolumn{7}{|l|}{ CV (\$/capita) } \\
\hline -Stone effect & -14.310 & -15.652 & -20.679 & -14.313 & -15.654 & -20.683 \\
\hline \multirow[t]{2}{*}{-Total effect } & -13.453 & -11.826 & -20.347 & -14.141 & -14.074 & -20.246 \\
\hline & $(1.072)$ & $(2.123)$ & (3.894) & $(1.124)$ & $(1.171)$ & $(2.426)$ \\
\hline Tax Burden & $0.047 \%$ & $0.028 \%$ & $0.055 \%$ & $0.049 \%$ & $0.033 \%$ & $0.055 \%$ \\
\hline
\end{tabular}

Note: Standard errors are reported in parentheses 
Table 6.Average Effects of a 20\% VAT on SSB on Daily Per Capita Energy and Nutrients Purchases across

Income

\begin{tabular}{|c|c|c|c|c|c|c|}
\hline & \multicolumn{3}{|c|}{ Household Production Model } & \multicolumn{3}{|c|}{ Ordinary Demand Model } \\
\hline & \multicolumn{3}{|c|}{ Aggregate Income Group } & \multicolumn{3}{|c|}{ Aggregate Income Group } \\
\hline & Calorie & Fat & Sodium & Calorie & Fat & Sodium \\
\hline \multirow[t]{2}{*}{ From SSB (kcal) } & -24.939 & -0.035 & -9.296 & -22.949 & -0.032 & -8.554 \\
\hline & $(8.322)$ & $(0.012)$ & $(3.102)$ & (7.294) & $(0.010)$ & $(2.719)$ \\
\hline \multirow[t]{4}{*}{ From all food categories (kcal) } & -29.166 & -0.249 & -14.228 & -15.647 & 0.337 & -0.034 \\
\hline & $(8.365)$ & $(0.033)$ & $(3.205)$ & $(7.722)$ & $(0.139)$ & $(4.139)$ \\
\hline & \multicolumn{3}{|c|}{ Low-income Group } & \multicolumn{3}{|c|}{ Low-income Group } \\
\hline & Calorie & Fat & Sodium & Calorie & Fat & Sodium \\
\hline \multirow[t]{2}{*}{ From SSB (kcal) } & -22.594 & -0.032 & -8.220 & -18.230 & -0.026 & -6.632 \\
\hline & $(9.397)$ & $(0.013)$ & $(3.419)$ & $(8.264)$ & $(0.012)$ & $(3.007)$ \\
\hline \multirow[t]{4}{*}{ From all food categories (kcal) } & -26.888 & -0.250 & -13.242 & -13.134 & 0.233 & -0.673 \\
\hline & $(9.439)$ & $(0.042)$ & (3.548) & $(8.648)$ & $(0.141)$ & $(4.370)$ \\
\hline & \multicolumn{3}{|c|}{ High-income Group } & \multicolumn{3}{|c|}{ High-income Group } \\
\hline & Calorie & Fat & Sodium & Calorie & Fat & Sodium \\
\hline \multirow[t]{2}{*}{ From SSB (kcal) } & -27.209 & -0.038 & -10.353 & -31.341 & -0.044 & -11.926 \\
\hline & $(11.715)$ & $(0.016)$ & $(4.458)$ & $(10.986)$ & $(0.015)$ & $(4.180)$ \\
\hline \multirow[t]{2}{*}{ From all food categories (kcal) } & -31.692 & -0.264 & -15.575 & -21.515 & 0.452 & -0.481 \\
\hline & $(11.763)$ & $(0.037)$ & $(4.556)$ & $(11.665)$ & $(0.215)$ & $(6.393)$ \\
\hline
\end{tabular}

Note: Standard errors are reported in parentheses. 
Table 7.Average Effects of a $20 \%$ VAT on SSB on Daily Per Capita Energy and Nutrients Purchases by Demographic Status

\begin{tabular}{|c|c|c|c|c|c|c|}
\hline & \multicolumn{3}{|c|}{ Household Production Model } & \multicolumn{3}{|c|}{ Ordinary Demand Model } \\
\hline & \multicolumn{3}{|c|}{ Households with kids } & \multicolumn{3}{|c|}{ Households with kids } \\
\hline & Calorie & Fat & Sodium & Calorie & Fat & Sodium \\
\hline \multirow[t]{2}{*}{ From SSB (kcal) } & -26.850 & -0.038 & -10.105 & -17.557 & -0.025 & -6.607 \\
\hline & $(13.319)$ & $(0.019)$ & $(5.013)$ & $(9.178)$ & $(0.013)$ & $(3.454)$ \\
\hline \multirow[t]{4}{*}{ From all food categories (kcal) } & -29.962 & -0.194 & -13.721 & -4.236 & 0.643 & 8.874 \\
\hline & $(13.341)$ & $(0.032)$ & $(5.062)$ & $(10.032)$ & $(0.208)$ & $(5.907)$ \\
\hline & \multicolumn{3}{|c|}{ Couples without kids } & \multicolumn{3}{|c|}{ Couples without kids } \\
\hline & Calorie & Fat & Sodium & Calorie & Fat & Sodium \\
\hline \multirow[t]{2}{*}{ From SSB (kcal) } & -66.070 & -0.094 & -24.178 & -29.776 & -0.042 & -10.897 \\
\hline & $(26.680)$ & $(0.038)$ & $(9.763)$ & $(12.817)$ & $(0.018)$ & $(4.690)$ \\
\hline \multirow[t]{4}{*}{ From all food categories (kcal) } & -69.870 & -0.288 & -28.597 & -27.743 & 0.062 & -8.533 \\
\hline & $(26.732)$ & $(0.075)$ & $(9.903)$ & $(13.651)$ & $(0.253)$ & $(7.346)$ \\
\hline & \multicolumn{3}{|c|}{ Single-adult } & \multicolumn{3}{|c|}{ Single-adult } \\
\hline & Calorie & Fat & Sodium & Calorie & Fat & Sodium \\
\hline \multirow[t]{2}{*}{ From SSB (kcal) } & -27.838 & -0.039 & -10.346 & -26.948 & -0.038 & -10.015 \\
\hline & $(33.408)$ & $(0.047)$ & (12.416) & (18.798) & $(0.026)$ & $(6.986)$ \\
\hline \multirow[t]{2}{*}{ From all food categories (kcal) } & -31.508 & -0.225 & -14.692 & -21.537 & 0.236 & -3.607 \\
\hline & $(33.516)$ & $(0.092)$ & $(12.632)$ & $(19.390)$ & $(0.281)$ & $(9.404)$ \\
\hline
\end{tabular}

Note: Standard errors are reported in parentheses. 


\section{Appendix A}

Table A1. Common Food Sub-categories in CEX and ERS Price Datasets

\begin{tabular}{|c|c|}
\hline \multicolumn{2}{|r|}{ Food Subcategories } \\
\hline & Cereal(Unprepared) \\
\hline 1 & Flour; Prepared flour mixes \\
\hline 2 & Cereal; Rice; White Bread; Bread other than White \\
\hline 3 & Pasta; cornmeal; other cereal products \\
\hline \multicolumn{2}{|r|}{ Cakes and Crackers } \\
\hline 4 & $\begin{array}{l}\text { Fresh biscuits, rolls, muffins; Bread and cracker products; Doughnuts, sweet rolls, coffeecakes, fresh } \\
\text { and other, excluding frozen; Frozen refrigerated and canned bakery products, such as biscuits, rolls, } \\
\text { muffins, cakes, cupcakes, doughnuts, pies, tarts, turnovers, and miscellaneous products, including } \\
\text { dough and batter; Pies, tarts, turnovers, fresh and other, excluding frozen }\end{array}$ \\
\hline 5 & $\begin{array}{l}\text { Cakes and cupcakes, fresh and other, excluding frozen; Cookies, excluding refrigerated dough; } \\
\text { Crackers, excluding crumbs }\end{array}$ \\
\hline \multicolumn{2}{|r|}{ Meat } \\
\hline 6 & $\begin{array}{l}\text { Ground beef, excluding canned; Bacon; Ham, excluding canned; Other pork, excluding canned; Pork } \\
\text { sausage, exclud ing canned; Frankfurters, excluding canned; Bologna, liverwurst, salami, excluding } \\
\text { canned; Lamb and organ meats, excluding canned; Mutton, goat, game }\end{array}$ \\
\hline 7 & $\begin{array}{l}\text { Chuck roast, excluding canned; Round roast, excluding canned; Other beef roast, excluding canned; } \\
\text { Round steak, excluding canned; Sirloin steak, excluding canned; Other steak, excluding canned; } \\
\text { Other beef, excluding canned; Pork chops }\end{array}$ \\
\hline 8 & $\begin{array}{l}\text { Canned ham; Miscellaneous prepared foods including items such as canned meats, fresh and canned } \\
\text { ethnic foods, fresh and canned pizza; Other lunchmeat }\end{array}$ \\
\hline 9 & Fresh and frozen whole chicken; Fresh or frozen chicken parts; Other poultry \\
\hline \multicolumn{2}{|r|}{ Fish } \\
\hline 10 & Canned fish, seafood and shellfish \\
\hline 11 & Fresh fish and shellfish; Frozen fish and shellfish \\
\hline \multicolumn{2}{|r|}{ Egg } \\
\hline 12 & Eggs \\
\hline \multicolumn{2}{|r|}{ Dairy } \\
\hline 13 & Fresh milk all types; Cream \\
\hline 14 & Butter; Margarine \\
\hline 15 & Cheese \\
\hline 16 & Ice cream and related products, including frozen y ogurt \\
\hline 17 & Other dairy products, including powdered milk, and fresh, canned and non-frozen yogurt \\
\hline & Fruits and Vegetables \\
\hline 18 & $\begin{array}{l}\text { Apples; Bananas; Oranges; Other fresh fruits; Citrus fruits excluding oranges; Frozen fruits; Canned } \\
\text { fruits }\end{array}$ \\
\hline 19 & Potatoes \\
\hline
\end{tabular}


Food Subcategories

\begin{tabular}{|c|c|}
\hline 20 & Lettuce \\
\hline 21 & Tomatoes \\
\hline 22 & Other fresh vegetables \\
\hline 23 & Frozen orange juice; Frozen fruit juices; Fresh fruit juices; Canned/bottled fruit juices \\
\hline 24 & Frozen vegetables \\
\hline 25 & Canned beans; Canned corn \\
\hline 26 & Miscellaneous canned vegetables, not collected in a separate UCC \\
\hline \multirow[t]{2}{*}{27} & Dried peas; Dried beans \\
\hline & Fat and oil \\
\hline \multirow[t]{2}{*}{28} & Fats and oils \\
\hline & Peanut butter \\
\hline \multirow[t]{2}{*}{29} & Peanut butter \\
\hline & $S S B$ \\
\hline 30 & Cola drinks; Other carbonated drinks \\
\hline \multirow[t]{2}{*}{31} & Noncarbonated fruit flavored drinks, including lemonade-non frozen; Sports Drinks \\
\hline & Frozen meal \\
\hline 32 & Soup; Frozen meals; Prepared desserts \\
\hline \multirow[t]{2}{*}{33} & Frozen prepared food other than meals \\
\hline & Chips and Snacks \\
\hline \multirow[t]{2}{*}{34} & Potato chips and other snacks \\
\hline & Nut \\
\hline \multirow[t]{2}{*}{35} & Nuts \\
\hline & FAFH \\
\hline 36 & Lunch at Fast Food; Dinner at Fast Food; Breakfast at Fast Food; \\
\hline 37 & Lunch at Full Service; Dinner at Full Service; Breakfast at Full Service \\
\hline
\end{tabular}




\section{Appendix B}

In the first stage, a linear regression is applied using ATUS (2015) to estimate the time use for FAH.

$T_{F A H}^{T U S}=\boldsymbol{Z}^{T U S^{\prime}} \boldsymbol{\delta}+\boldsymbol{u}$

where $T_{F A H}^{T U S}$ is the daily time use for food cooking/serving/clean up. The explanatory variables contained in $\boldsymbol{Z}^{\boldsymbol{T} U \boldsymbol{S}}$ include reference person's gender, age, race, Hispanic origin, households' highest education (a vector of indicators of less than high school, some college, bachelor, master or more), dummy variables of having children or not, variables ind icating children age distribution (Number of children under 5, Number of children 6 to 12, Number of children 13 to17), adults household members' total working time, household type (couple or single), household income and number of people aged greater than $65 ; \boldsymbol{\delta}$ is the related coefficients. Error term is denoted as $\mathbf{u}$.

Ordinary Least Squares (OLS) estimation is applied to estimate equation (b1), and the estimated coefficients $\widehat{\boldsymbol{\delta}}$ are obtained. The estimated coefficients are reported in the Appendix C Table $\mathrm{C} 1$. The imputed time for $\mathrm{FAH}$ is $\widehat{T}_{F A H}^{C E X}$, which is constructed by using $\widehat{\boldsymbol{\delta}}$ and same set of explanatory variables in CEX(2015). ${ }^{43}$

$\widehat{T}_{F A H}^{C E X}=Z^{C E X^{\prime}} \widehat{\delta}$

The time input for producing one unit of FAH (denoted by $\hat{t}_{F A H}^{C E X}$ ) is calculated by dividing total time used for FAH into quantity of FAH $\left(z_{1}\right)$

$\hat{t}_{F A H}^{C E X}=\frac{\widehat{T}_{F A H}^{C E X}}{z_{1}}$

The full price of FAH thus equals

\footnotetext{
${ }^{43}$ The imputed $\widehat{T}_{\mathrm{FAH}}^{C E X}$ is converted into weekly basis by multiplying it for seven.
} 
$\hat{p}_{1}^{F}=p_{1}+w \hat{t}_{F A H}^{C E X}$

where $\hat{p}_{1}^{F}$ is the estimated full price of FAH. The full price vector is thus expressed as $\widehat{\boldsymbol{p}}^{F}=\left[\hat{p}_{1}^{F}, p_{2}, p_{3}, w\right]$.

In the second stage, the EASI demand system is estimated. A seemingly unrelated regression (SUR) is used to estimate equation (b5) and (b6).

$s_{i h}{ }^{F}=\sum_{k=1}^{J} \alpha_{i k} \ln \left(\widehat{p_{k h}}{ }^{F}\right)+\sum_{r=0}^{R} \beta_{i r} y_{h}^{r}+\sum_{t=1}^{T} \gamma_{i t} z_{t h}+e_{i h}$

$y_{h}=\ln M_{h}^{F}-\sum_{k=1}^{J} \bar{s}_{k}^{F} \ln \left({\widehat{p_{k h}}}^{F}\right)$

$i=1, \ldots, J-1 h=1, \ldots, H$

where $\widehat{p_{k h}} F$ is the estimated full price for good $k$ in household $h$. 


\section{Appendix C}

Table C1. Estimated Coefficients of the First Stage Estimation

\begin{tabular}{|c|c|c|}
\hline Variable & Coef. & Robust Std. Err. \\
\hline Gender $($ Female $=0)$ & $-3.926 * * *$ & 1.110 \\
\hline Ages & $0.123 * * *$ & 0.057 \\
\hline \multicolumn{3}{|l|}{ Education } \\
\hline high school and less & -1.106 & 1.828 \\
\hline Associate degree & -1.836 & 1.725 \\
\hline bachelor & $-3.862 * *$ & 1.626 \\
\hline Master and above & 0.000 & (omitted) \\
\hline Kids $(\mathrm{No}=0)$ & $6.652 * * *$ & 1.986 \\
\hline \multicolumn{3}{|l|}{ Number of Kids } \\
\hline Number of children under 5 & $11.689 * * *$ & 1.669 \\
\hline Number of children 6 to 12 years old & $11.653 * * *$ & 1.389 \\
\hline Number of children 13 to 17 years old & $-4.727 * * *$ & 1.504 \\
\hline Worktime & $-0.142 * * *$ & 0.028 \\
\hline race & $4.766 * * *$ & 1.310 \\
\hline Hispanic origin & $9.261 * * *$ & 1.612 \\
\hline Income $(\$ 1000)$ & $-0.055 * * *$ & 0.000 \\
\hline Household type $($ Married $=0)$ & $-48.651 * * *$ & 1.901 \\
\hline No. of people age greater than 65 & $3.056 * *$ & 1.353 \\
\hline Constant & $89.635 * * *$ & 4.837 \\
\hline$R$-square & $18.19 \%$ & \\
\hline
\end{tabular}

Note: * represents for the $10 \%$ significant level, ** represents for the $5 \%$ significant level, $* * *$ represents for the $1 \%$ significant level. Sample weights are used in the regression analysis.

Table $\mathrm{C} 1$ reports the estimated results for the first stage using pooling sample of

ATUS (2015). According to our estimation, female adults use more time cooking than male adults. Elder people also use more time cooking than young people. We also find master and above degree households use more time in cooking than bachelor degree households. Households with kids tend to use more time on FAH. We find that the number of kids at different age levels affect the time use for cooking /cleaning up. Households with younger kids use more time on FAH. The more kids a household have, the more time needed. In addition, we find households with more adults greater than 65 use more time on food production. We find that there is a negative relation between working time and time used for FAH. Single- 
adult households use less time in cooking compared with married-couple households. We also find higher income families use less time on FAH. 


\section{Appendix D}

Calculation of the consistent standard error from TS2SLS

A sequential two-stage estimator is one that depends in part on a consistent first-stage estimator. The major concern of applying TS2SLS is how to obtain the asymptotic covariance matrix of the second stage estimator to estimate standard errors. There are two commonly used methods to address this issue - Inoue and Solon(2010)'s method which originates from Murphy and Topel's (1986) two step estimator(e.g., Currie and Yelowitz, 2001; Berg,Pinger, and Schoch, 2016), and a bootstrap method (e.g., Bjorklund\&Jantti, 1997; Anderson, 2011; Olivetti and Paserman, 2015). In this paper, we follow Inoue and Solon (2010)'s approach, a simple version of the method is expressed as follows:

$\hat{\gamma}_{11}\left(\mathbb{X}_{1}^{\prime} \mathbb{X}_{1}\right)^{-1} \times\left\{1+\left[\left(\mathrm{n}_{1} / \mathrm{n}_{2}\right) \widehat{\beta}_{\mathrm{TS} 2 \mathrm{SLS}}^{\prime} \widehat{\Sigma}_{\eta} \widehat{\beta}_{\mathrm{TS} 2 \mathrm{SLS}} / \hat{\gamma}_{11}\right]\right\}$

Where $\hat{\gamma}_{11}$ is the sample mean squared residual from the second-stage regression. $\mathbb{X}_{1}$ is the predicted second -stage repressors. $n_{1}$ is the number of observations in the first sample. $\mathrm{n}_{2}$ is the number of observations in the second sample. In our paper, the first sample is CEX 2015, the second sample is ATUS 2015. The $\widehat{\beta}_{\mathrm{TS} 2 \mathrm{SLS}}$ is the estimated coefficients in the second stage. $\widehat{\Sigma}_{\eta}$ is a consistent estimate of the covariance matrixfor the first-stage disturbances. 


\section{Appendix E}

Money price elasticity vs. full price elasticity

The full-price elasticities represent the percentage of quantity demand change with respect to $1 \%$ of full price change. It can be expressed as:

$\varepsilon_{\mathrm{ik}}^{\mathrm{F}}=\frac{\% \Delta \mathrm{Q}_{\mathrm{i}}}{\% \Delta \mathrm{p}_{\mathrm{k}}^{\mathrm{F}}} \times 100 \%$

The money price elasticityis expressed as the percentage variation of quantity with respect to $1 \%$ of money price change. It is written as:

$\varepsilon_{\mathrm{ik}}=\frac{\% \Delta \mathrm{Q}_{\mathrm{i}}}{\% \Delta \mathrm{p}_{\mathrm{k}}} \times 100 \%$

Substituting equation (e1) into equation (e2), we obtain the price elasticity $\varepsilon_{\mathrm{ik}}=\frac{\% \Delta \mathrm{p}_{\mathrm{k}}{ }^{\mathrm{F}}}{\% \Delta \mathrm{p}_{\mathrm{k}}} \times \varepsilon_{\mathrm{ik}}{ }^{\mathrm{F}}$. Holding unit time cost $(w t)$ unchanged, the price elasticity is expressed as: ${ }^{44}$

$\varepsilon_{\mathrm{ik}}=\varepsilon_{\mathrm{ik}}^{\mathrm{F}} \times \frac{\mathrm{p}_{\mathrm{k}}}{\mathrm{p}_{\mathrm{k}}^{\mathrm{F}}}$

In the household production model, one might observe a full-price elasticity is always greater or equal to its price elasticity $\left(\varepsilon^{F} \geq \varepsilon\right.$ ), since a full price is always greater or equal to its money price $\left(\mathrm{p}^{\mathrm{F}} \geq \mathrm{p}\right)$.

\footnotetext{
${ }^{44}$ When holding unit time cost $(w t)$ unchanged, money price chan ges equals full price changes $\left(\Delta \mathrm{p}_{\mathrm{k}}{ }^{\mathrm{F}}=\Delta \mathrm{p}_{\mathrm{k}}\right)$.
} 


\section{Appendix F: Robustness exercise}

\section{Common demographic cell}

To construct common demographic cell, we use nine division cate gories, two marital status categories, three household highest education categories, four age ranges of the reference person, two sex categories of reference person, two young children categories (have children less than 6), and two older children categories (have children less than 18 but greater than 6). It yields 638 cells. ${ }^{45}$ For each cell in the ATUS dataset, the sample average of time spent on FAH is calculated and merged into the CEX by same demographic cells. At last, as a robustness check, we estimate the models using data which are linked through common demographic cells. The detailed results are reported in Appendix Table G2 and are consistent with our previous estimates. The own price elasticity of SSB is -1.046 (-1.410) in a household production model (ordinary demand model). The cross -price elasticity between SSB and FAH is negative and statistically significant in the household production model, demonstrating that they are complements while they are substitutes in an ordinary demand model.

\section{Variation in Food Classifications}

Regarding to the food classification, we first perform a two-stage budgeting method as a robustness exercise. In the first stage, based on "time" usage, a household allocates their full bud gets into unprepared/semi prepared FAH, prepared

\footnotetext{
${ }^{45}$ Theoretically, it would yield 1728 cells. However, no observations exist in some cells. After removing these blank cells, we remain with 638 cells.
} 
FAH, limited-service FAFH (fast food) and full-service FAFH (table service). ${ }^{46}$ Unprepared/semi prepared FAH is a "home" produced good with both time and expenditure involved in the production. Prepared FAH is a market good which contains SSB, milk\& dairy product, juice, Chips\&Snacks, and cakes \& Crackers. In addition, limited-service FAFH and full-service FAFH are both market goods. ${ }^{47}$ Only after the allocations to these broad sectors have been specified, does the household decide how to split each sectorial expenditure among its component parts. Therefore, in the second stage, within prepared FAH, a household allocates its bud get into SSB, Fruit Juice, Milk\& other dairy, Chips\&S nacks, and Cakes\&Crackers. In the empirical estimation, we test the food aggregation based on Lewbel(1997)'s generalized composite commodity theorem. It requires the ratio of the prices of individual goods to group prices be independent of the level of group prices (and of total expenditures).Based on our estimation, we find that SSB, Milk, Juice, Chips\&S nacks and Cakes\&Crackers are able to be aggregated into one category.

We calculate the unconditional elasticities based on Capentier and Guyomard (2001)'s method. ${ }^{48}$ As discussed in the main text, The disadvantage of using this

\footnotetext{
${ }^{46}$ A time composite numeraire and a money composite numeraire are included in all the robustness exercises.

${ }^{47}$ The difference between the two is that Fast-food requires almost no waiting time.

${ }^{48}$ The unconditional Hicksian elasiticities in different groups are: $\widetilde{\Sigma_{1 j}}=w_{(H) j} \widetilde{\Sigma_{G H}} \eta_{(G) i} \eta_{(H) j}$ where where $\widetilde{\Sigma_{1 j}}$ is the unconditional Hicksian cross-price elasticities of commodity $i \in G$ with respect to the price of commodity $j \in H$, $\mathrm{G} \neq \mathrm{H}$, where $\mathrm{w}_{(\mathrm{H}) \mathrm{j}}$ is the budget share of commodity $\mathrm{j}$ with respect to group $\mathrm{H}$ expenditure, $\widetilde{\Sigma_{\mathrm{GH}}}$ is the Hicksiancross-price elasticity of aggregate good $G$ with respect to the price of aggregate good $H, \eta_{(G) i}$ is the conditional expenditure elasticity for commodity $i$, and $\eta_{(H) j}$ is the conditional expenditure elasticity for commodity j. The unconditional Hicksian elasiticities in the same group are: $\widetilde{\Sigma_{1 j}}=\widetilde{\varepsilon_{1 j}}+w_{(G) j} \widetilde{\Sigma_{G G}} \eta_{(G) i} \eta_{(G) j}$, where $\widetilde{\varepsilon_{1 j}}$ is the conditional Hicksian price elasticity of commodity $i \in I_{G}$ with respect to the price of commodity $j \in I_{G}$.
} 
two-stage demand analysis is that the unconditional elasticities are obtained using conditional elasticities in both first and second stage estimation, as a result, the standard errors of estimated elasticities cannot be obtained through common estimation method. The calculated elasticities are reported in Appendix Table G3 (1)-(3).We find that the estimated own-price elasticity of SSB is more elastic than the baseline model (-1.821 vs. -1.414$)$. Consistent with the baseline model, the own price elasticity for unprepared/semi prepared FAH is revealed to be price inelastic (0.263). This robustness exercise also provides evidence that when time inputs are included in the home food production, the home produced food ("unprepared/semi prepared FAH") is a complement to SSB. ${ }^{49}$

In addition, once juice, milk\&dairy products,chips\&snacks and cakes\&cracker are isolated from the aggregated $\mathrm{FAH}$, and classified into the prepared $\mathrm{FAH}$, we find that the within group substitution effect between chips\&snacks and SSB is significant - a price increase in SSB will increase chips\&snacks' intake. We find that due to this within group substitution effect between SSB and Chips\&Snacks, the overall reduction of energy caused by a price increase in SSB will be attenuated. Compared with the baseline household production model, this robust exercise implies a less reduction in energy intake (-29.2kcal vs. $-20.9 \mathrm{kcal})$.

In our third robustness exercise, food is disaggregated into eight groups Unprepared/Semiprepared FAH, SSB, Milk\&dairy products, Juice, Chips\&Snacks,

\footnotetext{
${ }^{49}$ The first stage budgeting implies that the unprepared/semi prepared FAH and prepared FAH are complements and are statistically significant. By using the second stage within group elasticities, we are able to calculate the unconditional elasticities between the home produced food (unprepared/semi prepared FAH) and SSB.
} 
Cakes\&Crackers, limited-service FAFH, and full-service FAFH. Among them, unprepared/semi prepared FAH is a household produced good, the rests are market goods. Similar as our baseline specification, an incomplete LA/EASI model is used to perform the empirical estimation. Appendix Table G4 reports the estimated elasticities. ${ }^{50}$ The own price elasticity for SSB is -1.413 , which is very close to our baseline model (-1.414). Again, SSB and the "home" produced good ("unprepared/semi-prepared FAH") are discovered to be complements with the cross price elasticity of -0.015 . In addition, this disaggre gated classification approach demonstrates that there is no significant substitutability/complementaty effects between SSB and the other market goods, except for full-service FAFH, which is discovered to be a complement to SSB. A simulation of a $20 \%$ price increase in SSB implies that when using this disaggregated food classification, the estimated reduction in calorie is slightly more than the baseline model (-29.2kcal vs. $-32.7 \mathrm{kcal})$.

\footnotetext{
${ }^{50}$ In both of the above robustness exercises, food is more disaggregated than our baseline model. We use Heckman two-step method to deal with the censoring issue.
} 


\section{Appendix G}

TableG1.Hicksian price elasticities varied by income quintile (household production model vs. ordinary EASI demand model)

\begin{tabular}{|c|c|c|c|c|c|c|c|}
\hline \multicolumn{4}{|c|}{ Household Production Model } & \multicolumn{4}{|c|}{ Ordinary EASI Demand Model } \\
\hline \multicolumn{4}{|c|}{ Aggregate } & \multicolumn{4}{|c|}{ Aggregate } \\
\hline & P_FAH & P_SSB & P_FAFH & & P_FAH & P_SSB & P_FAFH \\
\hline \multirow[t]{2}{*}{ FAH } & -0.306 & -0.013 & -0.001 & FAH & -0.159 & 0.036 & 0.110 \\
\hline & $(0.021)$ & $(0.002)$ & $(0.012)$ & & $(0.076)$ & $(0.014)$ & $(0.064)$ \\
\hline \multirow[t]{2}{*}{ SSB } & -0.129 & -1.412 & -0.128 & SSB & 1.158 & -1.890 & -0.285 \\
\hline & $(0.081)$ & $(0.465)$ & $(0.121)$ & & $(0.453)$ & $(0.408)$ & $(0.319)$ \\
\hline \multirow[t]{4}{*}{ FAFH } & -0.008 & -0.012 & -0.585 & FAFH & 0.172 & -0.014 & -0.341 \\
\hline & $(0.044)$ & $(0.011)$ & $(0.074)$ & & $(0.100)$ & $(0.016)$ & $(0.073)$ \\
\hline & \multicolumn{3}{|c|}{ Low } & \multicolumn{4}{|c|}{ Low } \\
\hline & P_FAH & P_SSB & P_FAFH & & P_FAH & P_SSB & P_FAFH \\
\hline \multirow[t]{2}{*}{ FAH } & -0.372 & -0.015 & -0.002 & FAH & -0.275 & 0.026 & 0.109 \\
\hline & $(0.030)$ & (0.003) & $(0.017)$ & & (0.134) & $(0.014)$ & $(0.074)$ \\
\hline \multirow[t]{2}{*}{ SSB } & -0.144 & -1.481 & -0.156 & SSB & 0.771 & -1.582 & -0.370 \\
\hline & (0.106) & $(0.616)$ & $(0.151)$ & & $(0.475)$ & $(0.542)$ & $(0.343)$ \\
\hline \multirow[t]{4}{*}{ FAFH } & -0.003 & -0.018 & -0.624 & FAFH & 0.220 & -0.026 & -0.343 \\
\hline & $(0.067)$ & $(0.018)$ & (0.109) & & (0.149) & $(0.024)$ & $(0.163)$ \\
\hline & \multicolumn{3}{|c|}{ High } & \multicolumn{4}{|c|}{ High } \\
\hline & P_FAH & P_SSB & P_FAFH & & P_FAH & P_SSB & P_FAFH \\
\hline \multirow[t]{2}{*}{ FAH } & -0.257 & -0.012 & -0.001 & FAH & -0.381 & 0.032 & 0.074 \\
\hline & (0.019) & $(0.002)$ & $(0.014)$ & & (0.095) & $(0.014)$ & $(0.058)$ \\
\hline \multirow[t]{2}{*}{ SSB } & -0.128 & -1.236 & 0.032 & SSB & 1.005 & -2.050 & 0.106 \\
\hline & (0.094) & $(0.556)$ & $(0.154)$ & & $(0.437)$ & $(1.080)$ & $(0.306)$ \\
\hline \multirow[t]{2}{*}{ FAFH } & 0.001 & 0.002 & -0.515 & FAFH & 0.094 & 0.004 & -0.412 \\
\hline & $(0.047)$ & $(0.010)$ & $(0.087)$ & & $(0.074)$ & $(0.012)$ & (0.106) \\
\hline
\end{tabular}

Note: Standard errors are reported in parentheses. Only selected elasticities (FAH, SSB and FAFH) that are our direct interests in this researchare reported; the elasticity of "othertime" in the household production model are not reported. 
Table G2. Estimated uncompensated elasticities using data of demographic cells

\begin{tabular}{|c|c|c|c|c|c|c|c|}
\hline \multicolumn{4}{|c|}{ Household Production Model } & \multicolumn{4}{|c|}{ Ordinary EASI Demand Model } \\
\hline \multicolumn{4}{|c|}{ Aggregate } & \multicolumn{4}{|c|}{ Aggregate } \\
\hline & P_FAH & P_SSB & P_FAFH & & P_FAH & P_SSB & P_FAFH \\
\hline FAH & $(0.009)$ & $(0.002)$ & $(0.015)$ & & $(0.185)$ & $(0.019)$ & $(0.088)$ \\
\hline SSB & -0.082 & -1.046 & -0.450 & SSB & 0.582 & -1.410 & -0.364 \\
\hline FAFH & $(0.016)$ & $(0.020)$ & $(0.135)$ & & $(0.133)$ & $(0.018)$ & $(0.127)$ \\
\hline
\end{tabular}

Note: Standard errors are reported in parentheses. Only selected elasticities (FAH, SSB and FAFH) that are our direct interests in this research are reported; the elasticity of "othertime" in the household production model are not reported. 
Table G3 (1). The first stage elasticities for composite commodity in a home production model

\begin{tabular}{lccccc}
\hline & Unprepared & prepared & Limited & Full-service & $\begin{array}{c}\text { Income } \\
\text { elasticity }\end{array}$ \\
\hline Price & & & & & \\
Unprepared/Semiprepared FAH & -0.263 & -0.087 & -0.003 & -0.016 & 1.308 \\
& $(0.020)$ & $(0.046)$ & $(0.054)$ & $(0.065)$ & $(0.058)$ \\
Prepared FAH & -0.054 & -0.245 & 0.015 & -0.085 & 1.807 \\
& $(0.006)$ & $(0.164)$ & $(0.069)$ & $(0.137)$ & $(0.127)$ \\
Limited service FAFH & -0.002 & 0.016 & -1.084 & -0.175 & 0.867 \\
& $(0.008)$ & $(0.076)$ & $(0.103)$ & $(0.114)$ & $(0.153)$ \\
Full-service FAFH & -0.012 & -0.101 & -0.190 & -1.416 & 0.968 \\
& $(0.010)$ & $(0.163)$ & $(0.124)$ & $(0.301)$ & $(0.182)$ \\
\hline
\end{tabular}

Note: Standard errors are reported in the parentheses.The elasticities of "othertime" in the household production model are not reported.

Table G3 (2).The second stage conditional elasticities of prepared FAH in a home production model

\begin{tabular}{|c|c|c|c|c|c|c|}
\hline & SSB & $\begin{array}{l}\text { Milk\& } \\
\text { otherDairy }\end{array}$ & Juice & $\begin{array}{l}\text { Chips } \\
\text { \&Snacks }\end{array}$ & $\begin{array}{l}\text { Crackers\&Cak } \\
\text { e }\end{array}$ & $\begin{array}{l}\text { Expenditure } \\
\text { elasticity }\end{array}$ \\
\hline \multicolumn{7}{|l|}{ Price } \\
\hline \multirow[t]{2}{*}{ SSB } & -1.769 & 0.129 & 0.210 & 1.211 & 0.462 & 1.010 \\
\hline & $(0.394)$ & $(0.164)$ & $(0.585)$ & $(0.458)$ & $(0.431)$ & $(0.003)$ \\
\hline \multirow[t]{2}{*}{ Milk\&otherDairy } & 0.165 & -0.680 & 0.030 & 0.352 & 0.313 & 0.984 \\
\hline & $(0.043)$ & $(0.032)$ & $(0.078)$ & $(0.061)$ & $(0.036)$ & $(0.002)$ \\
\hline \multirow[t]{2}{*}{ Juice } & 1.021 & -0.370 & -1.055 & -0.053 & 0.086 & 0.982 \\
\hline & $(0.326)$ & $(0.199)$ & $(0.982)$ & $(0.439)$ & $(0.237)$ & $(0.007)$ \\
\hline \multirow[t]{2}{*}{ Chips \&Snacks } & 0.052 & 0.232 & 0.892 & -1.183 & 0.143 & 1.005 \\
\hline & $(0.095)$ & $(0.058)$ & $(0.265)$ & $(0.106)$ & $(0.054)$ & $(0.003)$ \\
\hline \multirow[t]{2}{*}{ Crackers\&Cake } & 0.223 & 0.282 & 0.225 & 0.310 & -0.722 & 1.011 \\
\hline & $(0.019)$ & $(0.010)$ & $(0.050)$ & $(0.025)$ & $(0.021)$ & $(0.003)$ \\
\hline
\end{tabular}

Note: Standard errors are reported in the parentheses.

Table G3 (3). The unconditional money-price elasticities in the home production model

\begin{tabular}{lllllll}
\hline & SSB & $\begin{array}{l}\text { Milk\& } \\
\text { Other Dairy }\end{array}$ & Juice & $\begin{array}{l}\text { Chips\& } \\
\text { Snacks }\end{array}$ & $\begin{array}{l}\text { Crackers \& } \\
\text { Cakes }\end{array}$ & $\begin{array}{l}\text { Unprepared/ } \\
\text { Semiprepared FAH }\end{array}$ \\
\hline $\begin{array}{l}\text { Price } \\
\text { SSB }\end{array}$ & $\mathbf{- 1 . 8 2 1}$ & 0.078 & 0.160 & $\mathbf{1 . 1 5 9}$ & 0.410 & $\mathbf{- 0 . 0 1 1}$ \\
Milk\&otherDairy & 0.097 & -0.746 & -0.035 & 0.285 & 0.446 & -0.015 \\
Juice & 0.998 & -0.393 & -1.077 & -0.076 & 0.062 & -0.005 \\
Chips \&Snacks & -0.017 & 0.165 & 0.825 & -1.252 & 0.074 & -0.015 \\
Crackers\&Cake & 0.188 & 0.248 & 0.191 & 0.275 & -0.758 & -0.015 \\
$\begin{array}{l}\text { Unprepared/Semiprepared } \\
\text { FAH }\end{array}$ & -0.088 & -0.085 & -0.085 & -0.087 & -0.088 & $\mathbf{- 0 . 2 6 3}$ \\
\hline
\end{tabular}


Table G4. The Mashallian price elasticities across food using the home production model with disaggregated categories

\begin{tabular}{|c|c|c|c|c|c|c|c|c|}
\hline & SSB & $\begin{array}{l}\text { Milk\& } \\
\text { Other Dairy }\end{array}$ & Juice & $\begin{array}{l}\text { Chips\& } \\
\text { Crackers }\end{array}$ & $\begin{array}{l}\text { Cakes\& } \\
\text { Snacks }\end{array}$ & $\begin{array}{l}\text { Unprepared/ } \\
\text { Semiprepared } \\
\text { FAH }\end{array}$ & $\begin{array}{l}\text { Limited service } \\
\text { FAFH }\end{array}$ & $\begin{array}{l}\text { Full Service } \\
\text { FAFH }\end{array}$ \\
\hline \multicolumn{9}{|l|}{ Price } \\
\hline \multirow[t]{2}{*}{ SSB } & -1.413 & -0.044 & 0.818 & -0.546 & -0.029 & -0.015 & -0.028 & -0.230 \\
\hline & $(0.456)$ & $(0.108)$ & $(0.601)$ & $(0.470)$ & $(0.178)$ & $(0.002)$ & $(0.029)$ & $(0.062)$ \\
\hline \multirow[t]{2}{*}{ Milk\&Dairy } & -0.048 & -0.504 & -0.107 & 0.283 & 0.198 & -0.015 & 0.012 & 0.054 \\
\hline & $(0.119)$ & $(0.096)$ & $(0.166)$ & $(0.135)$ & $(0.101)$ & $(0.002)$ & $(0.024)$ & $(0.049)$ \\
\hline \multirow[t]{2}{*}{ Juice } & 0.321 & -0.037 & -1.651 & 1.951 & 0.018 & -0.006 & 0.014 & 0.033 \\
\hline & $(0.235)$ & $(0.059)$ & (1.088) & $(0.600)$ & $(0.101)$ & $(0.001)$ & $(0.016)$ & $(0.033)$ \\
\hline \multirow[t]{2}{*}{ Chips\&Snacks } & -0.368 & 0.172 & 3.362 & -3.422 & 0.191 & -0.009 & -0.008 & -0.005 \\
\hline & $(0.316)$ & $(0.082)$ & (1.034) & $(1.121)$ & $(0.141)$ & $(0.002)$ & $(0.022)$ & $(0.046)$ \\
\hline \multirow[t]{2}{*}{ Cakes\&Crackers } & -0.035 & 0.223 & 0.057 & 0.356 & -0.955 & -0.018 & 0.007 & 0.002 \\
\hline & $(0.223)$ & $(0.114)$ & $(0.323)$ & $(0.262)$ & $(0.234)$ & $(0.003)$ & $(0.035)$ & $(0.074)$ \\
\hline \multirow{2}{*}{$\begin{array}{l}\text { Unprepared/Semiprepared } \\
\text { FAH }\end{array}$} & -0.109 & -0.100 & -0.120 & -0.096 & -0.105 & -0.271 & -0.007 & -0.024 \\
\hline & $(0.080)$ & $(0.062)$ & $(0.100)$ & $(0.081)$ & $(0.077)$ & $(0.019)$ & $(0.054)$ & $(0.065)$ \\
\hline \multirow[t]{2}{*}{ Limited service FAFH } & -0.141 & 0.051 & 0.168 & -0.067 & 0.024 & -0.006 & -1.080 & -0.182 \\
\hline & $(0.145)$ & $(0.107)$ & $(0.201)$ & $(0.163)$ & $(0.141)$ & $(0.008)$ & $(0.102)$ & $(0.113)$ \\
\hline \multirow[t]{2}{*}{ Full service FAFH } & -1.243 & 0.259 & 0.449 & -0.047 & 0.003 & -0.020 & -0.196 & -1.454 \\
\hline & $(0.337)$ & $(0.236)$ & $(0.452)$ & $(0.364)$ & $(0.317)$ & $(0.010)$ & $(0.121)$ & $(0.297)$ \\
\hline
\end{tabular}

Note: Standard errors are reported in the parentheses. The elasticities of "othertime" in the household production model are not reported 


\section{Appendix H}

Table H1. The average adult BMI, weight, and height cross income and demographic status

\begin{tabular}{llll}
\hline & Aggregate & Low-income & High-income \\
BMI & 27.780 & 28.359 & 27.780 \\
Weight (in pounds) & 176.833 & 177.256 & 176.397 \\
Height (in inches) & 66.763 & 66.203 & 67.339 \\
& & \\
& Couples without kids & Couples with kids & Single-adult \\
BMI & 27.121 & 28.160 & 28.068 \\
Weight(in pounds) & 175.605 & 180.457 & 176.124 \\
Height(in inches) & 67.276 & 66.984 & 66.319 \\
\hline
\end{tabular}

Note: The BMI, weight, and height are averaged across groups, regardless of gender. The data source is from

ATUS- Eating and Health module (2015) 